\title{
To what extend can soil moisture and soil contamination stresses affect greenhouse gas emissions? An attempt to calibrate a nitrification/denitrification model
}

\footnotetext{
Laura Sereni ${ }^{*}$, Bertrand Guenet ${ }^{2}$, Charlotte Blasi $^{1,3}$, Olivier Crouzet ${ }^{1,4}$, Jean-Christophe Lata ${ }^{5,6}$ $5 \quad$ Isabelle Lamy ${ }^{1}$

${ }^{1}$ Université Paris-Saclay, INRAE, AgroParisTech, UMR ECOSYS, Ecotoxicology Team, 78026, Versailles, France

${ }^{2}$ Laboratoire de Géologie de l'ENS, PSL Research University, CNRS, UMR 8538, IPSL, Paris, France

${ }^{3}$ Present address: Centre Sève, Département de Chimie, Université de Sherbrooke, Sherbrooke, QC, Canada

$10{ }^{4}$ Present address: Office national de la chasse et de la faune sauvage, Site d'Auffargis-Saint-Benoist 78612 LePerray-en-Yvelines, France

${ }^{5}$ Sorbonne Université, Université de Paris, UPEC, CNRS, INRAE, IRD, UMR 7618, Institute of Ecology and Environmental Sciences - Paris, iEES Paris, 7 quai St Bernard 75252, Paris, France

${ }^{6}$ Department of Geoecology and Geochemistry, Institute of Natural Resources, Tomsk Polytechnic University, 30, Lenin Street, Tomsk, 634050, Russia
}

*Correspondence to Laura Sereni (laura.sereni@inrae.fr) 


\begin{abstract}
Continental biogeochemical models are commonly used to prospect the effect of land use, exogenous organic matter input or climate change on soil greenhouse gas emission. However, they can still not be used to investigate the effect of soil contamination while it is known to affect several soil processes and to concern a large fraction of land surface. We implemented a commonly used model estimating soil nitrogen $(\mathrm{N})$ emission, the DeNitrification DeCompostion (DNDC) model, with a function taking into account soil copper $(\mathrm{Cu})$ contamination in nitrate production modulation. Then, we aimed at using this model to predict $\mathrm{N}-\mathrm{N}_{2} \mathrm{O}, \mathrm{N}-\mathrm{NO}_{2} \mathrm{NOx}$ and $\mathrm{N}-\mathrm{NH}_{4}$ emissions in the presence of contamination and in the context of changes in precipitations. For that, incubations of soils were performed at different soil moistures in order to mimic expected rainfall patterns during the next decades and in particular drought and excess of water. The effect of this double stress on soil nitrate production was studied using a bio-assay. Then, data of nitrate production obtained under each moisture treatment were used to parameterize the DNDC model and estimate soil $\mathrm{N}$ emission considering the various effect of $\mathrm{Cu}$. Whatever the moisture preincubation, experimental results showed a $\mathrm{N}-\mathrm{NO}_{3}$ decreasing production when $\mathrm{Cu}$ was added but with different sharpness depending on soil moisture. The DNDC-Cu version we proposed was able to reproduce these observed $\mathrm{Cu}$ effects on soil nitrate concentration with $\mathrm{r} 2>0.99$ and $\mathrm{RMSE}<10 \%$ for all treatments in the DNDC-Cu calibration range ( $>40 \%$ of the water holding capacity) but showed poor performances for the dry treatments. We modelled a Cu-effect inducing an increase in $\mathrm{N}^{-N_{4}}$ soil concentration and emissions due to a reduced nitrification activity, and therefore a decrease in $\mathrm{N}-\mathrm{NO}_{3}, \mathrm{~N}-\mathrm{N}_{2} \mathrm{O}$ and $\mathrm{N}-\mathrm{NOx}$ concentrations and emissions. The effect of added $\mathrm{Cu}$ was larger on $\mathrm{N}-\mathrm{N}_{2}$ and $\mathrm{N}-\mathrm{N}_{2} \mathrm{O}$ emissions than on the other $\mathrm{N}$ species and larger for the soils incubated under constant than variable moisture.
\end{abstract}

Keywords: copper, DNDC modelling, rainfall pattern, ecotoxicology, soil function 


\section{Introduction}

The increase in atmospheric greenhouse gases [GHG] like $\mathrm{CO}_{2}, \mathrm{CH}_{4}$, or $\mathrm{N}_{2} \mathrm{O}$ is expected to induce a global climate change with e.g. higher mean temperature or changes in precipitation patterns with projections of increased precipitations or droughts depending on regions (Knutti and Sedláček 2012). These modifications in rainfall patterns may impact soil moisture which is one of the main drivers of soil microbial activity (Moyano et al. 2013). Microbial communities ensure key activities supporting numerous ecosystem functions, such as those involved in nitrogen $(\mathrm{N})$ cycle influencing $\mathrm{N}_{2} \mathrm{O}$ emissions (Jones et al. 2014) and are at the origin of more than $80 \%$ of $\mathrm{N}_{2} \mathrm{O}$ fluxes (IPCC 2019). In particular, nitrification/denitrification processes are largely controlled by the local (an-)oxic treatments and therefore by soil moisture, denitrification being the main source of soil $\mathrm{N}_{2} \mathrm{O}$ emission for moist soils whereas dry soil $\mathrm{N}_{2} \mathrm{O}$ emissions are mainly due to nitrification (Bateman and Baggs 2005). This strong dependency to local soil $\mathrm{O}_{2}$ availability (Khalil et al. 2004), by playing on the realization of nitrification/denitrification reactions and N species diffusion (Conrad 1996; Schurgers et al. 2006), makes N soil fluxes dynamics particularly difficult to predict at larger scales. Despite this, some continental biogeochemical have shown improved predictions when $\mathrm{N}$ cycle is explicitly represented (Kesik et al. 2005; Butterbach-Bahl et al. 2009; Vuichard et al. 2018).

In addition to climate change, human activities introduce significant quantities of contaminants into the environment, such as trace elements (TE) which are persistent and can be toxic for soil biota (Bech et al. 1997; Giller et al. 2009). Indeed, the contamination of soils by TE has become a major concern at global scale (De Vleeschouwer et al. 2007; Khan et al. 2008) coming from atmospheric sources (Steinnes et al. 1997) or through the use of pesticides (Nicholson et al. 2003). In particular, TE contaminations are known to largely affect soil microorganisms (Giller et al. 2009) and their activities, such as nitrification/denitrification processes (Broos et al. 2007; Mertens et al. 2010). Therefore, the combined effect of climate change and of soil contamination may largely impact the emissions of $\mathrm{NO}_{\mathrm{x}}$ and $\mathrm{N}_{2} \mathrm{O}$ from soils (Holtan-Hartwig et al., 2002; Vásquez-Murrieta et al. 2006). However, the effect of the interactions between climate change and soil contamination on the GHG emissions is still poorly documented (Rillig et al. 2019; Zandalinas et al. 2021).

Despite recent progress, the Earth system models (ESMs) used to predict future climate change still don't take into account soil contamination effect on GHG emissions (Anav et al. 2013) whereas a large fraction of the soils are impacted by contaminants (Lado et al. 2008). Furthermore, soil biogeochemical models are often used to estimate loss or accumulation of $\mathrm{N}$ species (ammoniac $\mathrm{NH}_{4}$ volatilization, nitrate $\mathrm{NO}_{3}$ leaching - Giltrap et al. 70 2010) or they respective concentrations under scenarii of organic fertilizer amendments, but do not take into account the contamination which often occurs simultaneously (Wuana and Okieimen 2011). Thus, there is a growing need to provide continentals models combining ecotoxicological/contamination and climate change concerns. Among biogeochemical models DeNitrification DeCompostion (DNDC, Changsheng Li et al. 1992) is a relatively simple model handling both biogeochemistry of denitrification and microbial growth (Li et al. 2000), and on which Land Surface Model-soil N component -a part of ESMs- like ORCHIDEE are built (Vuichard et al. 2018).

For this purpose, this study combines in an innovative way experimental and modelling approaches in order to evaluate the impact of soil moisture on the sensitivity of nitrification to copper $(\mathrm{Cu})$ toxicity and 
consequently on N-GHG emissions. $\mathrm{Cu}$ was chosen as a model of soil contamination due to its relevance in agricultural soils and available data in the literature. Soil incubations were run during two months by applying chosen soil moisture from drought to water saturation. Then, a bioassay estimating $\mathrm{NO}_{3}$ production was performed under a gradient of $\mathrm{Cu}$ added by spiking. The experimental data were then used to calibrate a new model, DNDC$\mathrm{Cu}$, able to predict $\mathrm{NO}_{\mathrm{x}}$ and $\mathrm{N}_{2} \mathrm{O}$ emissions with the implementation of new functions to consider the effect of $\mathrm{Cu}$ concentration $([\mathrm{Cu}])$ on nitrification/denitrification processes. Our hypothesis is that the building of such a model will permit to gain in understanding on the effect of a soil $[\mathrm{Cu}]$ on $\mathrm{NO}_{\mathrm{x}}$ and $\mathrm{N}_{2} \mathrm{O}$ and $\mathrm{NH}_{4}$ cycling in a climate change context. Hence, data are also used here to discuss on knowledge gaps in such modelling approaches, and to question the use of soil contamination data in climate change scenarios.

\section{Materials and Methods}

\subsection{Soil sampling}

The soil was sampled in January 2017 at the surface layer $(0-20 \mathrm{~cm})$ of a control plot at the Qualiagro experimental site $\left(48^{\circ} 87^{\prime} \mathrm{N}, 1^{\circ} 97^{\prime} \mathrm{E}\right.$ - https://www6.inrae.fr/valor-pro_eng/Experimental-devices/QualiAgro/QualiAgro-website). The soil sample was immediately wet sieved at $5 \mathrm{~mm}$ and shortly stored at $4^{\circ} \mathrm{C}$ until microcosm build-up. Aliquots of this sieved soil were used to measure the initial water content in addition to the maximum water holding capacity (WHC) for the further microcosm experiments. This site is located at Feucherolles near Paris, France, and had been designed to evaluate urban compost fertility together with the monitoring of contaminant inputs (Cambier et al. 2019). Soil is a luvisol with $15 \%$ clay, $78 \%$ silt and $7 \%$ sand, a pH of 6.9 , organic carbon (Corg) and total $\mathrm{N}$ contents at $10.5 \pm 0.2$ and $1.00 \pm 0.03 \mathrm{~g} \mathrm{~kg}^{-1}$ soil, respectively, and with a CEC of $7.9 \pm 0.8$ $\mathrm{cmol}^{+} \mathrm{kg}^{-1}$ soil. This soil is not contaminated with $\mathrm{Cu}$, and basal $[\mathrm{Cu}]$ measured by ICP-AES after $\mathrm{HF}_{-} \mathrm{HClO}_{4}$ extraction was of $12 \mathrm{mg} \mathrm{Cu} \cdot \mathrm{kg}^{-1}$ soil.

\subsection{Experimental setup}

In order to evaluate the impact of soil moisture on the sensitivity of nitrification to $\mathrm{Cu}$ toxicity, we carried out a two-step experiment. The first step consisted in 5 different WHC incubation during 45 days, and the second to a 3-day bioassay with spiked $\mathrm{Cu}$ gradient (Fig. 1).

Five microcosms were built up with about $5 \mathrm{~g}$ of sampled soil. Three of them were set up with a constant moisture corresponding to $30 \%, 60 \%$ and $90 \%$ of their WHC in order to span respectively limiting, optimal, and saturating conditions for the microbial activities. These three samples will be called thereafter " $30 \%, 60 \%$ and $90 \%$ ", respectively. Their water contents were verified by weighting every two days and water added if necessary. The two other microcosms were incubated in order to simulate two kinds of drought and dry-rewetting cycles.

110 One, thereafter called "Drought" (or DO), started with one week at 60\% WHC and then the soil was left for 3 weeks without added water to mimic a dry period until $10 \%$ of the WHC before rewetting at the initial $60 \%$ WHC. The other, thereafter called "Dry-rewetting" (or DR) encountered alternatives cycles of one-week dry period (10\% of the WHC) followed by one-week near-saturation period (90\% WHC). The moisture states of microcosms were performed by air-drying and controlled by weighting. 

soils and following an adaptation of the method proposed by Petersen et al. (2012). Soils were first spiked with a gradient of increasing $\mathrm{Cu}^{2+}$ in the presence of an excess of $\mathrm{NH}_{4}{ }^{+}$and the resulting potential nitrification activity (PNA) measured. The microcosms incubated at constant moisture were kept at their moisture level (30, 60 or 90\% of WHC) whereas those incubated at variable moisture were set at $60 \% \mathrm{WHC}$. The $\mathrm{NO}_{3}$-production rates were measured in soil slurries over a short-term aerobic incubation, for each $\mathrm{Cu}$ added concentration. Briefly, $1 \mathrm{~mL}$ of $\mathrm{Cu}$ solution at different concentrations were added in soil slurries (soil solution 1:12) to reach final added [Cu] of 50, 100, 250, 500, 750,1000 and $2000 \mathrm{mg} \mathrm{Cu} . \mathrm{kg} \mathrm{soil}^{-1}$ (final soil $[\mathrm{Cu}]$ of 62, 112, 262, 512, 762, 1012 and 2012 $\left.\mathrm{mg} \mathrm{Cu} . \mathrm{kg} \mathrm{soil}^{-1}\right)$. The $\mathrm{pH}$ was adjusted to 7 . Then, microcosms were incubated on a rotary shaker (150rpm) under aerobic conditions at $25^{\circ} \mathrm{C}$ until $72 \mathrm{~h}$. After 0,24 and $72 \mathrm{~h}$ of incubation, $2 \mathrm{ml}$ aliquots of $3 \mathrm{~g}$ were transferred in Eppendorf vials and centrifuged. The supernatants were collected and stored in microplates at $-20{ }^{\circ} \mathrm{C}$ until analyses of $\mathrm{NO}_{3}^{-}$and $\mathrm{NO}_{2}^{-}$by colorimetric determinations, following the reduction of $\mathrm{NO}_{3}^{-}$in $\mathrm{NO}_{2}^{-}$by vanadium(III) and then the detection of $\mathrm{NO}_{2}^{-}$by the acidic Griess reaction (Miranda et al. 2001). Finally, PNA ( $\mu \mathrm{g}$

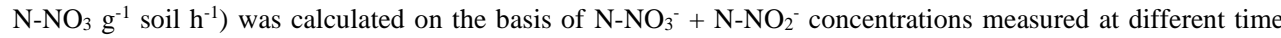
steps. In our bioassay, $\left[\mathrm{NO}_{2}^{-}\right]$were negligible and PNA was thus calculated following Eq. (1), by checking the linear production rate of $\mathrm{NO}_{3}^{-}$between $2 \mathrm{~h}, 24 \mathrm{~h}$ and $72 \mathrm{~h}$ :

$$
\text { (1) } P N A=\frac{\left[\mathrm{NO}_{3}^{-}\right]_{\text {ffinal }}-\left[\mathrm{NO}_{3}^{-}\right]_{\text {Tinitial }}}{\text { ffinal }- \text { Tinitial }_{\text {Tin }}} \times V S \div W
$$

with Vs: Volume of solution

$W$ : Weight of fresh soil (approximately $5 \mathrm{~g}$ )

$T$ : Time of incubation.

\subsection{Nitrification/denitrification model}

Nitrification and denitrification processes are represented following the DNDC model proposed by Changsheng $\mathrm{Li}$ et al. (1992) and $\mathrm{Li}$ et al. (2000). In this study, we used a simplified version adapted by Zaehle and Friend (2010) initially calibrated for soil WHC $>40 \%$, that we intended here to test for $30 \%$ of WHC. This simplified version needs less boundary data but keeps a mechanistic description of the main processes. Modelled $\mathrm{N}$ species are expressed in amount of $\mathrm{N}$, i.e. $\mathrm{N}-\mathrm{NH}_{4}, \mathrm{~N}-\mathrm{NO}_{3}, \mathrm{~N}-\mathrm{NOx}$ and $\mathrm{N}-\mathrm{N}_{2} \mathrm{O}$. To be able to represent both nitrification and denitrification processes occurring in aerobic and anaerobic sites, the soil is split into aerobic and anaerobic fractions based on an empirical relationship linking $\mathrm{O}_{2}$ consumption to soil respiration. In aerobic microsites, nitrification takes places following Eq. (2):

(2) Nitrification $=f(S W C) \times f(t e m p) \times f(p H) \times k_{\text {Nit }} \times(1-$ anvf $) \times N_{4}$ with $\mathrm{N}-\mathrm{NH}_{4}$ being the stock of ammonium (in $\left.\mathrm{gN} \mathrm{m}^{-2}\right),(1-a n v f)$ the aerobic fraction of the soil described thereafter in Eq. (21), $k_{N i t}$ the nitrification rate $\left(\mathrm{day}^{-1}\right), f(S W C), f($ temp $)$ and $f(p H)$ three rate modifiers representing the effect of soil water content $\left(\mathrm{m}^{3} \mathrm{~m}^{-3}\right)$, temperature $(\mathrm{K})$ and $\mathrm{pH}$ as scalar respectively. They are described by the following Eq. (3), (4) and (5):

(3) $f(S W C)=0.0243+0.9975 \times S W C+5.6358 \times S W C^{2}+17.651 \times S W C^{3}+12.904 \times S W C^{4}$ 
$(4) f($ temp $)=0.0233+0.3094 \times t e m p+0.2234 \times t e m p^{2}+0.1566 \times t e m p^{3}+0.0272 \times$ temp $p^{4}$

(5) $f(p H)=1.2314+0.7347 \times p H+0.0604 \times p H^{2}$

The $\mathrm{N}-\mathrm{NH}_{4}$ nitrified is transformed into $\mathrm{N}-\mathrm{N}_{2} \mathrm{O}, \mathrm{N}-\mathrm{NO}$ or $\mathrm{N}-\mathrm{NO}_{3}$ due to bacterial processes and chemonitrification following Eq. (6),(7) and (8):

(6) Nitrification $_{N 2 O}=f t v \times S W C \times k_{\text {Nitrif }_{N 2 O}} \times$ Nitrification

$$
\text { Nitrification }_{N O}=f t v \times S W C \times k_{\text {Nitrif }_{N O}} \times \text { Nitrification }+496950 \times e^{-1.62 \times p H} \times
$$

$e^{-31494 /(t e m p \times R)} \times$ Nitrification

160

(8) Nitrification $_{\mathrm{NO} 3}=$ Nitrification - Nitrification $_{\mathrm{NO}}-$ Nitrification $_{\mathrm{N} 2 \mathrm{O}}$

with $k_{\text {Nitrif }}$ and $k_{\text {Nitrif }}$ I2O $_{\text {Ono fixed rates }}\left(\mathrm{d}^{-1}\right)$, ftv a rate modifier controlled by temperature and given in Eq. (9) and $R$ the ideal gas constant.

(9) $f t v=2.72^{\left(34.6-\frac{9615}{\text { temp }}\right)}$

Then, the $\mathrm{N}-\mathrm{NO}_{3}$ produced during the nitrification process enters the denitrification module where it is reduced sequentially into $\mathrm{N}-\mathrm{NO}_{x}, \mathrm{~N}-\mathrm{N}_{2} \mathrm{O}$ or $\mathrm{N}-\mathrm{N}_{2}$ following Eq. (10) to (12):

(10) Denitrification $_{N O x}=$ anvf $\times\left(\frac{\mu_{N O 3}}{0.401}+0.09 \times \frac{N O_{3}}{N_{t o t}}\right) \times B$

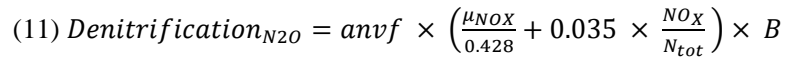

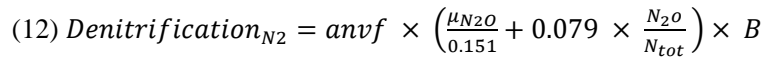

The anaerobic fraction anvf is described following Eq. (13):

(13) $a n v f=0.85 \times\left(1-\frac{p_{-} \text {soil }_{O 2}}{p_{-} \text {air }}\right)$

175

with $p_{-}$air $_{O 2}, p_{-}$soil $_{O 2}$ being the partial pressure in the air and in the soil respectively. $p_{-} s o i l_{O 2}$ is calculated following Eq. (14)

(14) $\frac{\partial p_{-} \text {soil }_{O 2}}{\partial t}=p_{-}$soil $_{O 2}-\times k \times S O C \times f_{C u}$ 

pressure related to the respiration, and $f_{C u}$ the effect of $\mathrm{Cu}$ on $\mathrm{CO}_{2}$ emissions as define in Eq.(15), following (Sereni et al. 2021; Eq. (5):

(15) $f_{\text {Cu co2 }}=\exp (-0.1-0.1 \times \log (C u)+0.12 \times p H)$

185

The relative growth rate of $\mathrm{N}-\mathrm{NO}_{3}, \mathrm{~N}^{-\mathrm{NO}_{\mathrm{x}}}$ and $\mathrm{N}-\mathrm{N}_{2} \mathrm{O}$ denitrifiers are described respectively by $\mu_{N O 3}, \mu_{N O X}, \mu_{N 2 O}$ following Eq. (16), (17) and (18).

(16) $\mu_{\mathrm{NO} 3}=\frac{0.67 \times f_{\text {denit }}(\text { temp }) \times f_{\text {denit_NO3 }}(p H) \times \mathrm{NO}_{3}}{N O_{3}+166}$

(17) $\mu_{\text {NOX }}=\frac{0.34 \times f_{\text {denit }}(t e m p) \times f_{\text {denit_NOX }}(p H) \times N O_{X}}{N O_{X}+166}$

(18) $\mu_{N 2 O}=\frac{0.34 \times f_{\text {denit }}(t e m p) \times f_{\text {denit } \_N 2 O}(p H) \times N_{2} O}{N_{2} O+166}$

with $f_{\text {denit }}($ temp $), f_{\text {denit_NO3 }}(p H), f_{\text {denit_NOX }}(p H), f_{\text {denit_N2O }}(p H)$ being rates modifiers depending on air temperature and soil $\mathrm{pH}$ described in Eq. (19) to (22).

195
(19) $f_{\text {denit }}($ temp $)=2^{(\text {temp-22.5)/10 }}$
(20) $f_{\text {denit_NO3 }}(p H)=1-\frac{1}{1+e^{(4.25 \times p H) / 0.5}}$
(21) $f_{\text {denit_NOX }}(p H)=1-\frac{1}{1+e^{(5.25 \times p H)}}$
(22) $f_{\text {denit_N2O }}(p H)=1-\frac{1}{1+e^{(6.25 \times p H) / 1.5}}$

200

The denitrifier biomass dynamic $B\left(\mathrm{~kg} \mathrm{~m}^{-2}\right)$ is described following Eq. (23).

(23) $\frac{\partial B}{\partial t}=\left(\operatorname{anvf} \times\left(\mu_{N O 3}+\mu_{N O X}+\mu_{N 2 O}\right)-3.82 \times 10^{-3}\right) \times B$

Finally, all the gaseous forms of mineral $\mathrm{N}$ are emitted into the atmosphere. We wrote the adapted model in $\mathrm{R}$, with a the time step of the model of 30 minutes and most of the parameters were kept to the original values of Changsheng $\mathrm{Li}$ et al. 1992; Li et al. 2000) except k_nit which was modified to 0.1743 instead of 0.2 to better fit the data from the control. Furthermore, the amounts of $\mathrm{N}^{-\mathrm{NH}_{4}}$ fixed to the clay were reduced to 0 as the bioassay was performed in excess of $\mathrm{N}-\mathrm{NH}_{4}$ (see 2.2.0).

We used measures of $\mathrm{N}$ species at the end of preincubation period as initial values of $\mathrm{N}$ species for DNDC (Table 1a and Fig. 2.). To estimate the anaerobic volume fraction during the 3 days bio-assay, we used a $\mathrm{C}$ mineralization rate $k$ (eq 14) determined on the basis of measurements performed on the same soil (Annabi et al. 2007) and ran DNDC for a 45 days equilibrium period. We then extracted the initial anaerobic volume fraction and partial $\mathrm{O}_{2}$ pressure.

\subsection{Statistical analysis}


The dose-response curves of PNA to $\mathrm{Cu}$ gradient were plotted and tested with linear, quadratic or cubic functions as fitting models. Our aim was to find, if possible, a similar modelling fit function for all moisture incubation treatments. Thus, for each moisture treatment, the two best functions of fit were selected through AIC and $\mathrm{R}^{2}$ criteria, and compared with ANOVA. After selection of a common type of functions, the permutability of the different functions parameters was tested with the Chow test (gap package which tested the regression 1 on the basis of the samples 2 and vice-versa). If the p-value exceeds its critical values, regressions cannot be considered equal (Zhao 2007)).

To estimate the effect of $[\mathrm{Cu}]$ and soil moisture on the different variables measured, we used nonparametric Kruskall-Wallis test. The fits between the model and the data were measured using root mean square error (RMSE, Eq. (24)):

(24) $R M S E=\sqrt{\frac{1}{N} \sum_{i=1}^{N}\left(X_{i}-Y_{i}\right)^{2}}$

where $i$ is the number of observations ( 1 to $\mathrm{N}$ ), $X$ is the predicted value and $Y$ is the observed value. RMSE was decomposed in standard bias (Eq. (25)), non-unity slope (Eq. (26)) and lack of correlation (Eq. (27)) component following Gauch et al. (2003), with $\bar{X}$ and $\bar{Y}$ the mean modelled and observed values, b the slope of the least squares regression of $\mathrm{Y}$ on $\mathrm{X}$ and $\mathrm{r}^{2}$ the square of the correlation:

(25) $: S B=(\bar{X}-\bar{Y})^{2}$

(26) $N U=(1-b)^{2} \times \sum \frac{x_{n}^{2}}{N}$

(27) $L C=\left(1-r^{2}\right) \times \sum \frac{y_{n}^{2}}{N}$

235 All the analysis were done with R 3.2.3 (R Core Team, 2015).

\section{Results}

\subsection{Effect of Cu on potential nitrification activity (PNA): statistical model selection}

The soil $\mathrm{N}$ species measured at the end of the soil pre-incubation in each soil moisture treatment were used to initialise the DNDC model (Table 1). Two anomalous points leading to anomalous calculated $\mathrm{N}-\mathrm{NO}_{2}$ values were excluded from the experimental results because of technical problems during measurements (the $\mathrm{C}$ replicates in the DR and DO cases).

The bioassay experiments performed at the end of the soil pre-incubation allowed us to determine the rate of nitrate production as a function of soil $[\mathrm{Cu}]$ for each soil moisture (Fig. 1). In all cases, the PNA was found to decrease with the increase in soil $[\mathrm{Cu}]$ but at different rates depending on the moisture treatment. Based on AIC (suppl. Table 1) values, we first selected the model that better fitted the data. For 30 and $60 \%$ of WHC, a quadratic model was found to provide the better compromise between the number of parameters and the prediction capacity for incubation. For $90 \%$ WHC, no significant difference was found between the cubic and the quadratic models 
(ANOVA, p.v=0.07). For DR, no significant difference was found between linear and quadratic models quadratic model (AIC and adj. R2 score, suppl table 1). Finally, we found that the quadratic model fitted correctly all the sets of data, allowing to be homogeneous across the moisture's incubation treatments (Fig. 2b). The quadratic function was thus chosen to quantify the $\mathrm{Cu}$ effect on PNA also for the DO treatment.

The parameters of the 5 quadratic functions (one for each moisture treatment) were found different from each other, except between 60 and $90 \%$ WHC (p.v=0.001, Chow test). A single function was thus used to adjust PNA to soil [Cu] at 60 and $90 \%$ WHC but with different intercepts for these two WHC treatments (suppl. Table 2 and Fig. 2).

The final 4 quadratic equations (Eq. (28) for 30\%WHC, Eq. (29) for 60 and 90\%WHC, Eq. (30) for DR, and Eq. (31) for DO, Fig. 2) were then added in the DNDC model, allowing to adjust the Eq. (2) which regulates the nitrate production to soil $\mathrm{Cu}$ contents:

$$
\begin{aligned}
& \text { (28) } F_{C u 30}=0.782-0.000451 \times C u+9.49 \times 10^{-8} \times C u^{2} \\
& \text { (29) } F_{C u 60 / 90}=b-0.000342 \times C u+4.30 \times 10^{-8} \times C u^{2}
\end{aligned}
$$

with $b=0.795$ for $60 \% \mathrm{WHC}$ and $\mathrm{b}=0.0 .79629$ for $90 \% \mathrm{WHC}$

$$
\text { (30) } F_{C u D R}=0.552-0.000164 \times C u+6.09 \times 10^{-8} \times C u^{2}
$$

$$
\text { (31) } F_{\text {CuDO }}=0.625-0.000192 \times C u+2.82 \times 10^{-8} \times C u^{2}
$$

\subsection{Modelling soil nitrate concentrations in $\mathrm{Cu}$ contaminated treatments using a DNDC-Cu model.}

\section{2.a. Set up of the DNDC-Cu model}

270 The DNDC model was originally constructed to model both $\mathrm{C}$ and $\mathrm{N}$ soil cycles. The relative proportion of nitrification and denitrification processes thus depends on soil aerobic fraction determined both by soil $\mathrm{C}$ respiration and soil moisture (Eqs. (13) and (14)). Before any addition of $\mathrm{Cu}$ function in DNDC, we estimated this soil aerobic fraction, arising from $\mathrm{C}$ mineralisation and the aerobic fraction. Therefore, we used previous data from 366 days incubations made on the same uncontaminated soil (Annabi et al. 2007) to first fit a $\mathrm{C}$ mineralisation coefficient rate, $\mathrm{k}$. The resulting $\mathrm{k}$ coefficient $\left(\mathrm{k}=1.234 \mathrm{e}^{-4} \mathrm{gC} \cdot \mathrm{m}^{-2} .30 \mathrm{~min}^{-1}\right)$ was introduced in the DNDC model and forced to equilibrium (45 days) without soil $\mathrm{Cu}$ contamination effect. This provided us a basal aerobic volume fraction for each soil moisture through Eq. (13) corresponding to 0.00352 at 30\%, 0.006167 at $60 \%$ (and DR/DO to which bio assays were performed at $60 \% \mathrm{WHC}$ ) and 0.02705 at $90 \%$ of the $\mathrm{WHC}$ and partial $\mathrm{O}_{2}$ pressure to $211.4 \mathrm{hPa}$ at $30 \% \mathrm{WHC}, 210.7 \mathrm{hPa}$ at $60 \% \mathrm{WHC}$, DR and DO and $205.4 \mathrm{hPa}$ at $90 \% \mathrm{WHC}$. These values were then used to initiate our DNDC-Cu version. We then ran the DNDC-Cu version for a 3-day modelisation. The constant rate of $\mathrm{C}$ mineralisation, $\mathrm{k}$, was adjusted to take into account $\mathrm{Cu}$ through the eq 13 and the eq 28-31 adjusted $\mathrm{N}-\mathrm{NO}_{3}$ production rate (Fig. 1) to $\mathrm{Cu}$. 


\section{2.b. DNDC-Cu model validation}

285 A validation of our DNDC-Cu model was made by comparing experimental data of soil measured after 1 and 3 days of incubation with model outputs. A better fit was provided for 60 and $90 \%$ of WHC which are in the range of DNDC calibration compared to $30 \% \mathrm{WHC}$ where the nitrate production is largely underestimated (more than twice after 3 days of incubation, Fig. 3a). The regression slopes between modelled and measured soil [nitrate] for 60 and 90\% WHC were respectively 0.94 and 0.91 (R2=0.99 in both cases, Fig. 3a.) whereas for 30\% WHC the regression slope was 1.21 (R2=0.92) (Fig. 3a). For DR, the soil nitrate stocks were overestimated at $762 \mathrm{mgCu} . \mathrm{kg}$ soil $^{-1}$ soil and underestimated at 2012 mgCu.kg soil ${ }^{-1}$ (Fig. 3b) (respectively 389.7 gN.m-2 and 310.5 gN.m ${ }^{-2}$ mean modeled nitrate against 375.3 and $290.6 \mathrm{gN} . \mathrm{m}^{-2}$ mean measured nitrate) but overall modelling adequately fitted the data with a regression slope at 0.95 and $\mathrm{R} 2=0.99$ too.

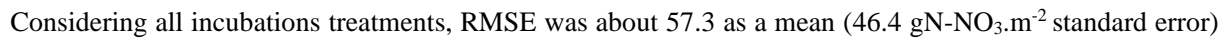
for a mean soil nitrate measured at $390 \mathrm{gN}-\mathrm{NO}_{3} \cdot \mathrm{m}^{-2}\left(69 \mathrm{gN}-\mathrm{NO}_{3} \cdot \mathrm{m}^{-2}\right.$ standard error) after 3 days of incubation. However, for the 30\% WHC, RMSE was 139.9 thus 3.7 times more than for the other treatments (Suppl. Fig. 1). Despite the reduction of nitrate production rate from 0.2000 to $0.1753 \mathrm{gN}$.hour ${ }^{-1}$ (see material and methods), soil nitrate stock was still slightly overestimated in the $90 \%$ WHC as shown by the largest lack of correlation in this case compared to the $60 \%$ WHC treatment (Fig. 3a, suppl. Fig. 1). Lack of correlation was small for all tested moisture incubation treatments (mean $\sqrt{L C}=23.0$, standard error $=5.4$ which is roughly $1 / 20$ of the produced nitrate in 3 days in uncontaminated treatment). Results showed that our DNDC-Cu version was able to reproduce the variability observed in $\mathrm{Cu}$ contaminated soils except for the $30 \%$ WHC treatment where soil nitrate stocks were largely underestimated. The following results thus focused on the use of DNDC-Cu for DR, DO, 60 and 90\% of WHC treatments to predict soil N emissions.

\subsection{Use of DNDC-Cu to predict N fluxes in contaminated soils.}

\section{3.a. Effect of soil $[\mathrm{Cu}]$ on soil $\mathrm{N}$ stocks.}

The soil $\mathrm{Cu}$ function we included in the DNDC-Cu model modified specifically the default nitrification equation in complement to $\mathrm{pH}$, soil moisture and $\mathrm{O}_{2}$ availability (Eq (2.)). In the presence of low [Cu] (12-512 mgCu.kg 310 soil $^{-1}$ ), the predicted $\mathrm{N}-\mathrm{NO}_{3}$ soil stocks were found equivalent between 60 and $\mathrm{DO}$ and, to a less extend, DR treatments (Suppl. Fig. 2). When soil $[\mathrm{Cu}]$ increased, soil $\left[\mathrm{N}-\mathrm{NO}_{3}\right]$ decreased but with different rates depending on the moisture of incubations (eq 28-31). Up to $548 \mathrm{mgCu} . \mathrm{kg}$ soil ${ }^{-1}$, we modelled the lowest $\mathrm{N}^{-\mathrm{NO}_{3}}$ stocks in DR incubated soils. Above it, $\mathrm{N}_{-} \mathrm{NO}_{3}$ soil stocks were the smallest for the $60 \%$ WHC treatment as a result of the sharpest decrease in $\mathrm{N}-\mathrm{NO}_{3}$ production due to soil $[\mathrm{Cu}] . \mathrm{N}-\mathrm{NO}_{3}$ soil stock for incubation at $90 \%$ WHC were the

315 highest for soil [Cu] below $1432 \mathrm{mgCu} . \mathrm{kg}$ soil ${ }^{-1}$. Between 1432 and $2000 \mathrm{mgCu} . \mathrm{kg} \mathrm{soil}{ }^{-1}, \mathrm{~N}-\mathrm{NO}_{3}$ soil stocks were similar for $90 \%$ WHC, DR and DO (Suppl. Fig. 2).

The decrease in the nitrification rates with the increase in soil $[\mathrm{Cu}]$ resulted in an increase in soil $\mathrm{N}-\mathrm{NH}_{4}$ stocks. Our model also predicted largest $\mathrm{N}^{-\mathrm{NH}_{4}}$ stocks in the DR and DO soils than in the 60 and $90 \%$ WHC soils 
(Suppl. Fig.3). The variations in $\mathrm{N}-\mathrm{NH}_{4}$ and $\mathrm{N}-\mathrm{NO}_{3}$ stocks were however different across soil moistures so that at the highest $[\mathrm{Cu}]$, the $\mathrm{N}-\mathrm{NH}_{4}$ soil stocks were modelled similar between all moisture treatments whereas the $\mathrm{N}^{-\mathrm{NO}_{3}}$ stocks were modelled smallest for the $60 \%$ WHC treatment. The $\mathrm{N}-\mathrm{NO}_{3} / \mathrm{N}-\mathrm{NH}_{4}$ stocks ratios thus varied between soil moistures with $\mathrm{Cu}$ levels whereas in the absence of $\mathrm{Cu}, \mathrm{N}-\mathrm{NO}_{3} / \mathrm{N}-\mathrm{NH}_{4}$ ratios were similar among soil moisture treatments. The ratio of $\mathrm{N}-\mathrm{NO}_{3} / \mathrm{N}-\mathrm{NH}_{4}$ decreased faster for $60 / 90 \%$ WHC than for DR/DO with an increase in soil [Cu] (suppl Fig. 4; Table 2).

With the decrease in soil $\mathrm{N}-\mathrm{NO}_{3}$ stocks at high $[\mathrm{Cu}]$, we predicted a decrease in the growth of denitrifying bacteria (Eq. (13)). Consequently, the modelled denitrifying bacterial pool was reduced when soil $[\mathrm{Cu}]$ increases (Fig. 4). Whatever the soil [Cu], denitrification was however modelled roughly twice larger in the soils incubated at $90 \%$ WHC than in the other treatment as this moist treatment is defined as perfect condition for denitrifying bacteria in the DNDC model (Changsheng Li et al. 1992). Soils incubated at $60 \%$ WHC were modeled with the lowest denitrifying bacterial pool. No difference between the DR and DO soils was found due to uncertainties in the modelled denitrifying bacterial pool which resulted from the different concentrations in $\mathrm{N}$ species used to initialize DNDC-Cu (Table 1). The soil $\mathrm{N}-\mathrm{N}_{2} \mathrm{O}$ stocks and dissolved N-NOx being directly related to denitrifying bacteria and its followed similar trends than soil $\mathrm{N}_{-} \mathrm{NO}_{3}$ stocks with a global decrease in soil stocks with an increase in soil $[\mathrm{Cu}]$ (table 2) and larger stocks at the wetter treatment.

\section{3.b. Estimation of soil $\mathrm{N}$ emissions under various moistures}

Large differences are predicted in the $\mathrm{N}-\mathrm{NH}_{4}, \mathrm{~N}-\mathrm{NOx}$ and $\mathrm{N}-\mathrm{N}_{2} \mathrm{O}$ fluxes between the $90 \%$ WHC soil and the 3 other soil moisture treatments (Fig. 5). For instance, we modelled a decrease comparable in N-NOx emissions between DR/DO and 60-90\% WHC for soil [Cu] about $112 \mathrm{mgCu}^{\mathrm{kg}}$ soil ${ }^{-1}$ (2-3\% respectively - Table 2a and 2b.) but with the increase in soil $[\mathrm{Cu}]$, the variation of emissions between soil moisture became larger. Hence, around $2012 \mathrm{mgCu} . \mathrm{kg} \mathrm{soil}^{-1}$ we modelled more than $50 \%$ decrease in N-NOx and $62 \%$ decrease in $\mathrm{N}-\mathrm{N}_{2} \mathrm{O}$ emission fluxes for soils at $60 \%$ WHC against only $40 \%$ decrease in $\mathrm{N}-\mathrm{NOx}$ and $54 \%$ in $\mathrm{N}-\mathrm{N}_{2} \mathrm{O}$ emission for soils previously exposed to DR (Tables 2a and b.). Thus, intensities of fluxes between two moisture treatments reversed with an increase in soil $\mathrm{Cu}$ contamination.

The smallest fluxes were predicted for the wetter treatment despite higher modelled $\mathrm{N}-\mathrm{N}_{2} \mathrm{O}$ stocks at $90 \%$ WHC whatever $[\mathrm{Cu}] . \mathrm{N}^{-\mathrm{NH}_{4}}$ fluxes were modelled higher for the DR soils than in the $60 \%$ WHC incubated for soil $\mathrm{Cu}$ higher than $1774 \mathrm{mgCu} . \mathrm{kg}$ soil ${ }^{-1}$ and smallest below. The emissions of $\mathrm{N}-\mathrm{NH}_{4}$ in the DO treatment were predicted to be higher than those of the DR treatment for soil Cu higher than $1290 \mathrm{mgCu} . \mathrm{kg} \mathrm{soil}^{-1}$ and smallest below (Fig. 5a). In the studied range of added $\mathrm{Cu}, \mathrm{N}-\mathrm{NOx}$ fluxes predicted by the model are largest from $60 \% \mathrm{WHC}$ to DO, DR and $90 \%$ WHC (Fig. 5(b.)) for moderate Cu input ( below $1380 \mathrm{mgCu} . \mathrm{kg}^{-1}$ soil $^{-1}$ ). The decrease in NNOx emission with the increase in soil [Cu] was however steeper for soils incubated at 60\%WHC. Hence, at 2012 mgCu.kg soil ${ }^{-1} \mathrm{~N}-\mathrm{NOx}$ fluxes in soil incubated at $60 \%$ WHC were similar to those in the soils incubated under

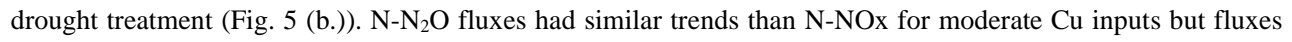
were still largest from $60 \%$ WHC to DO, DR and 90\% WHC (Fig. 5 (c.)). 
ratio of emitted $\mathrm{N}-\mathrm{N}_{2} \mathrm{O}$ per denitrification products (e.g N-N $\mathrm{N}_{2} \mathrm{O} / \mathrm{N}_{-} \mathrm{N}_{2} \mathrm{O}+\mathrm{N}-\mathrm{N}_{2}$ ) was hence smallest in the moistest

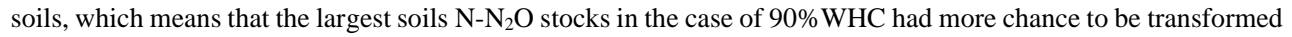
rather than emitted (Fig. 6).

\section{DISCUSSION}

\subsection{From laboratory experiment to soil $\mathrm{N}$ emission modelling}

Thanks to our laboratory experiments, we were able to define a function modulating the soil $\mathrm{N}-\mathrm{NO}_{3}$ production rates in relation with soil $[\mathrm{Cu}]$ and depending on the soil moisture. Our results showed that soil nitrate decreases with an increase in soil [Cu].

After implementing these $\mathrm{Cu}$ modulating functions into the DNDC-Cu model, we were able to reproduce the observed soil nitrate stock particularly for the soils incubated at 60 and $90 \%$ of WHC. The variability around the mean due to the $\mathrm{Cu}$ effect was also reproduced by our DNDC-Cu version at $30 \%$ of WHC despite strong underestimation of mean soil nitrate stocks due to model moisture-limit (Changsheng Li et al. 1992). In the case of the DR and DO incubated soils, the so-called "Cu function" also accounted for the effect of drought stress. In fact, our $\mathrm{Cu}$ functions were defined on the basis of soil nitrate production against the whole gradient of $\mathrm{Cu}$ thus also considering the control without $\mathrm{Cu}$. However, the (double) stress effect was also well reproduced in nitrate production.

In the present study, we predicted highest soil $\mathrm{N}-\mathrm{N}_{2}, \mathrm{~N}-\mathrm{N}_{2} \mathrm{O}$ and N-NOx stocks in the moistest treatments as they are produced by the denitrifying bacteria expected to behave optimally at $90 \%$ WHC or after DR cycles (Changsheng $\mathrm{Li}$ et al. 1992; Homyak et al. 2017). However, $\mathrm{N}-\mathrm{N}_{2} \mathrm{O}$ and $\mathrm{N}-\mathrm{NOx}$ emissions were modelled higher in the driest soils, whereas numerous studies (Dobbie and Smith 2003; Xiong et al. 2007; Manzoni et al. 2012) reported high measured $\mathrm{N}-\mathrm{N}_{2} \mathrm{O}$ emissions with high moisture. In the present version of DNDC-Cu, the soil $\mathrm{N}$ emissions were directly controlled by their diffusion in soil, calculated on the basis of clay and soil moisture content. The diffusion of each species would hence be 11 times smaller under 90\% WHC (D_s= 0.00357) than under the $60 \%$ WHC treatment (D_s=0.0306) because the model described the diffusion as a whole and do not separated pores with or without water. Diffusion was hence slower in the water than in the air. Thus, the weighted mean diffusion was lower in the high moisture treatment. Without $\mathrm{Cu}$ soil nitrous stocks being roughly 1.6 times and soils $\mathrm{N}-\mathrm{N}_{2}$ stocks 11.1 larger under $90 \%$ WHC treatment than the other, the emission of $\mathrm{N}^{-} \mathrm{N}_{2} \mathrm{O}$ were larger under driest treatment even if stocks were smaller.

Several studies also reported flushing event with dry rewetting cycles which would enhance $\mathrm{C}$ mineralisation, known as the Birch effect (Birch 1958; Göransson et al. 2013), hence reducing soil $\mathrm{O}_{2}$ concentration. Moreover, soil $\left[\mathrm{O}_{2}\right]$ is closely related to the pore size distribution, being of major importance in nitrification/denitrification 
control (Khalil et al. 2004) with a dominating nitrification for aggregates up to $0.25 \mathrm{~cm}$ (Kremen et al. 2005). Pore size distribution under dry/rewet events is controlled by cracking, (des)aggregation (Denef et al. 2001; Cosentino et al. 2006) or gas displacement (Kemper et al. 1985) that we weren't able to take into account in the present study. In DNDC, the calculation of denitrification rate and diffusion was based on a rough description of anaerobic zone with approximation of soil pore space distribution ( $\mathrm{Li}$ et al. 2000; Blagodatsky et al. 2011). The soil pore space distribution approach has been demonstrated to be more generally applicable (Arah and Vinten 1995; Schurgers et al. 2006) whereas soil aggregates have been shown to control the extend of nitrification and denitrification (Kremen et al. 2005; Schlüter et al. 2018). However, if models have been proposed to take $\mathrm{O}_{2}$ availability at the aggregate size into account in the nitrous oxide production (Leffelaar 1988; Kremen et al. 2005), they also point out the difficulty in parametrization which need a large panel of soil measurements. Moreover, they are rarely transposable at the meso-and regional scale due to high spatial variations in soil structure (Butterbach-Bahl et al. 2013). The DNDC-Cu version we used here particularly pointed out the difficulty in dealing on biogeochemistry model with physical processes, with large discrepancies between modelled soils stocks and emissions. The validation we performed focused on soil nitrates stocks and a second step to go further on would be the measure of gaseous species to ensure that emissions were also impacted by soils treatment. Moreover, we assumed here that soil $[\mathrm{Cu}]$ affected the $\mathrm{C}$ mineralisation with a decrease in soil $\mathrm{O}_{2}$ production leading to an increase in denitrification and $\mathrm{N}-\mathrm{N}_{2} \mathrm{O}, \mathrm{N}-\mathrm{NOx}$. Nevertheless, the present DNDC-Cu version didn't take into account the retroaction between $\mathrm{C}$ and $\mathrm{N}$ cycles. Further research would thus be required to include $\mathrm{Cu}$ contamination into $\mathrm{C}$ and $\mathrm{N}$ interacting cycles.

\subsection{Expected ecological implications of soil $\mathrm{Cu}$ contamination}

Based on nitrate production measurements, we modeled a decrease in denitrifying activities with an increase in soil $[\mathrm{Cu}]$ as a consequence of the decrease in soil nitrate stocks. However, the experiments performed here did not allow us to determine if the soil $\mathrm{Cu}$ contamination rather affects nitrifying bacteria (e.g. decrease in nitrifying activity and in $\mathrm{N}-\mathrm{NO}_{3}$ production) or denitrifying bacteria (e.g. increase in denitrifying activities and $\mathrm{N}-\mathrm{NO}_{3}$ consumption). The effect of soil contamination on $\mathrm{N}-\mathrm{N}_{2} \mathrm{O}$ production is debated because i) species involved are not clearly identified (Wrage-Mönnig et al. 2018), ii) species richness is not necessary related to soil functions (Ruyters et al. 2013) and iii) denitrifying communities could be differently sensitive than the nitrifying to soil contamination (Vásquez-Murrieta et al. 2006; Hund-Rinke and Simon 2008). Also, our modeling approach of N$\mathrm{N}_{2} \mathrm{O}, \mathrm{N}-\mathrm{N}_{2}$ and $\mathrm{N}-\mathrm{NOx}$ production in the contaminated context could have been more constrained with measurement of denitrification rate to assess the effect of $\mathrm{Cu}$ on proportion of production and consumption of $\mathrm{N}$ $\mathrm{NO}_{3}$

Based on our simulations, the soil $\mathrm{Cu}$ contamination wass expected to substantially modify the proportion of available $\mathrm{N}$ in soils with the increase in $\mathrm{N}-\mathrm{NH}_{4}$ stock at the expense of $\mathrm{N}-\mathrm{NO}_{3} . \mathrm{N}-\mathrm{NH}_{4}$ accumulation and the large expected decrease in $\mathrm{N}-\mathrm{NO}_{3} / \mathrm{N}-\mathrm{NH}_{4}$ ratio in contaminated soils (around $50 \%$ for the $60 \% \mathrm{WHC}$ ) may lead to shift in plant community structures with different preferences in $\mathrm{N}$ assimilation (Peacock et al. 2001; Cui and Song 2007). Therefore, $\mathrm{Cu}$ stress could not only have implications in microbial community patterns as a stressor, 


\subsection{Climate change could substantially modify contaminated soil $\mathrm{N}$ emission}

It is well known that climate change and rainfall patterns could substantially modify the soil $\mathrm{N}$ balance and its GHG emissions (Galloway et al. 2003, 2008; Butterbach-Bahl et al. 2013). Our results showed that increased $\mathrm{Cu}$ contamination as well might affect soil $\mathrm{N}$ emissions with smallest emissions of $\mathrm{N}-\mathrm{NOx}$ and $\mathrm{N}-\mathrm{N}_{2} \mathrm{O}$. These two gases are of major importance in GHG mitigation with a warming potential per mass 300 and 40 times greater than $\mathrm{CO}_{2}$, respectively. Agricultural soils being the dominating source of $\mathrm{N}-\mathrm{N}_{2} \mathrm{O}$ (Beauchamp 1997; Signor and Cerri 2013), even a limited decrease in their emissions could have major implication for climate. Based on our modelling, the join effect of soil moisture and $[\mathrm{Cu}]$ wass particularly important with larger differences in $\mathrm{N}-\mathrm{N}_{2} \mathrm{O}$ and N-NOx emissions between rainfall patterns at high $[\mathrm{Cu}]$ (3.3.b.). We (Sereni et al. in press) previously/also showed that soil $\mathrm{Cu}$ contamination differently affect soils nitrification depending of primary soil moisture stress. Here we showed that the $\mathrm{N}-\mathrm{N}_{2} \mathrm{O}$ and $\mathrm{N}-\mathrm{NOx}$ emission variations are significantly more sensitive to the combined effect of $\mathrm{Cu}$ and precipitation regime than the nitrate stock. Based on these results, soil $\mathrm{Cu}$ inputs on moistest soils would lead to a largest decrease in soil $\mathrm{N}_{-} \mathrm{N}_{2} \mathrm{O}$ and $\mathrm{N}-\mathrm{NOx}$ emission compared to that on driest soils, and even more than on soils submitted to abrupt and intense shifts in rainfall patterns as the DR and DO soils.

\section{CONCLUSION}

In the present study, we aimed at combining ecotoxicological experiments and biogeochemical modelling focusing on the effect of soil $\mathrm{Cu}$ contamination on soil $\mathrm{N}$ emission under different soil moisture treatments. Based on a 3 day bioassay measuring soil $\mathrm{N}-\mathrm{NO}_{3}$ over time, we were able to adjust the DNDC model to take into account the $\mathrm{Cu}$ effect on soil $\mathrm{N}$ emission. Experiments were performed under different moisture treatments to create a DNDC$\mathrm{Cu}$ model taking account the effect of an exposure to a constant moisture (30,60 or 90\%WHC) or to a single long drought period (DO) or several dry rewetting cycle (DR). The DNDC-Cu version we proposed was able to reproduce the observed $\mathrm{Cu}$ effect on soil nitrate stock with $\mathrm{r} 2>0.99$ and $\mathrm{RMSE}<10 \%$ for all treatments in the DNDC calibration range ( $>40 \% \mathrm{WHC})$.

We modelled a $\mathrm{Cu}$ effect inducing a decrease in denitrifying bacterial pool leading to an increase in $\mathrm{N}-\mathrm{NH}_{4}$ soil stocks at the expense of $\mathrm{N}-\mathrm{NO}_{3}, \mathrm{~N}-\mathrm{N}_{2} \mathrm{O}$ and $\mathrm{N}-\mathrm{NOx}$ stocks. Emissions of $\mathrm{N}^{-\mathrm{NH}_{4}}$ were expected to slightly increase with soil $\mathrm{Cu}$ contamination whereas those of $\mathrm{N}-\mathrm{N}_{2} \mathrm{O}$ and $\mathrm{N}-\mathrm{NOx}$ are expected to decrease. We also showed that the effect of soil $\mathrm{Cu}$ contamination was different among moisture treatment and $\mathrm{N}$ species. In fact, we modelled that the largest $[\mathrm{Cu}]\left(2012 \mathrm{mg} \mathrm{Cu} \cdot \mathrm{kg} \mathrm{soil}^{-1}\right)$ provoked a decrease in soil nitrate stocks from $-28 \%$ in the DR case to $-44 \%$ in the $60 \%$ WHC whereas $\mathrm{N}^{-} \mathrm{N}_{2} \mathrm{O}$ emission were expected to decrease up to $63 \%$ in the $90 \%$ WHC $\left(-62 \%\right.$ in the $60 \%$ WHC case, $-54 \%$ in the DO case). Our results tended to show that the amount of $\mathrm{N}^{-\mathrm{N}_{2} \mathrm{O}}$ emitted from denitrification would decrease with an increase in soil $[\mathrm{Cu}]$ and from $60 \%$ WHC to DR, DO and $90 \%$ WHC, so that less $\mathrm{N}-\mathrm{N}_{2} \mathrm{O}$ produced would be converted to $\mathrm{N}-\mathrm{N}_{2}$. This result points out two main difficulties 
https://doi.org/10.5194/bg-2021-265

Preprint. Discussion started: 3 November 2021

(c) Author(s) 2021. CC BY 4.0 License.

in biogeochemical modelling: i) the difficulty to take into account hydrological dynamics (produced $\mathrm{N}-\mathrm{NO}_{3}$ and $\mathrm{N}-\mathrm{NH}_{4}$ could be expected to leach) and soil structures at different spatial scale (denitrification is estimated based on rough estimation on anaerobic soil volume which also controlled emissions rates through diffusion processes) and ii) linking soil function to microbial dynamics, in particular in this case were only the $\mathrm{N}^{-\mathrm{NO}_{3}}$ stock was measured (without dealing between production and consumption for instance). Despite these two main points of uncertainty, the combination of incubations and of modelisation we conducted here emphasize the need to account for soil contamination when dealing with soil GHG emission modelling and climate change, as both contamination and rainfall patterns affect in a different way the soil N-NOx and $\mathrm{N}-\mathrm{N}_{2} \mathrm{O}$ emissions.

Data availability: Data are available at https://doi.org/10.15454/ZUKN90

Authors Contributions: the authors contributed as follows:

Laura Sereni: Methodology, Formal analysis, Data processing, Writing original draft.

Bertrand Guenet: Methodology, conceptualization, writing review and editing, supervision

Charlotte Blasi: Experimentations and draft initialization

Olivier Crouzet: Methodology, conceptualization, writing review and editing, supervision

Jean-Christophe Lata: writing review and editing, supervision

Isabelle Lamy: Methodology Conceptualization, Writing review and editing, Supervision Project administration, Funding acquisition.

Competing Interests: authors have no competing interests to declare.

Acknowledgments

Parts of this study were financially supported by the French National Research Agency ANR CESA-13-0016-01 through the CEMABS project and the Labex BASC through the Connexion project. LS thanks the Ecole Normale Supérieure (ENS) for funding her PhD. The authors thank Amélie Trouvé for her help in soil data analysis, Sébastien Breuil for soil processing and Christelle Marrauld for bioassay design.

\section{References}

Anav a., Friedlingstein P, Kidston M, et al (2013) Evaluating the Land and Ocean Components of the Global Carbon Cycle in the Cmip5 Earth System Models. J Clim 130401082723008. https://doi.org/10.1175/JCLI-D-12-00417.1

Annabi M, Houot S, Francou C, et al (2007) Soil Aggregate Stability Improvement with Urban Composts of Different Maturities. Soil Sci Soc Am J 71:413-423. https://doi.org/10.2136/sssaj2006.0161

Arah Jrm, Vinten Aja (1995) Simplified Models Of Anoxia And Denitrification In Aggregated And SimpleStructured Soils. Eur J Soil Sci. Https://Doi.Org/10.1111/J.1365-2389.1995.Tb01347.X 
Bateman EJ, Baggs EM (2005) Contributions of nitrification and denitrification to N2O emissions from soils at different water-filled pore space. Biol Fertil Soils 41:379-388. https://doi.org/10.1007/s00374-005-0858-3

Beauchamp EG (1997) Nitrous oxide emission from agricultural soils. In: Canadian Journal of Soil Science

Bech J, Poschenrieder C, Llugany M, et al (1997) Arsenic and heavy metal contamination of soil and vegetation around a copper mine in Northern Peru. Sci Total Environ. https://doi.org/10.1016/S0048-9697(97)001368

Birch HF (1958) The effect of soil drying on humus decomposition and nitrogen availability. Plant Soil. https://doi.org/10.1007/BF01343734

Blagodatsky S, Grote R, Kiese R, et al (2011) Modelling of microbial carbon and nitrogen turnover in soil with special emphasis on $\mathrm{N}$-trace gases emission

Broos K, Warne MSJ, Heemsbergen DA, et al (2007) Soil factors controlling the toxicity of copper and zinc to microbial processes in Australian soils. Environ Toxicol Chem 26:583-590. https://doi.org/10.1897/06302R.1

Butterbach-Bahl K, Baggs EM, Dannenmann M, et al (2013) Nitrous oxide emissions from soils: How well do we understand the processes and their controls? Philos Trans R Soc B Biol Sci 368: https://doi.org/10.1098/rstb.2013.0122

Butterbach-Bahl K, Kahl M, Mykhayliv L, et al (2009) A European-wide inventory of soil NO emissions using the biogeochemical models DNDC/Forest-DNDC. Atmos Environ 43:1392-1402. https://doi.org/10.1016/j.atmosenv.2008.02.008

Cambier P, Michaud A, Paradelo R, et al (2019) Trace metal availability in soil horizons amended with various urban waste composts during 17 years - Monitoring and modelling. Sci Total Environ 651:2961-2974. https://doi.org/10.1016/j.scitotenv.2018.10.013

Changsheng Li, Frolking S, Frolking TA (1992) A model of nitrous oxide evolution from soil driven by rainfall events: 1. Model structure and sensitivity. J Geophys Res. https://doi.org/10.1029/92jd00509

Conrad R (1996) Soil microorganisms as controllers of atmospheric trace gases (H2, CO, CH4, OCS, N2O, and NO). Microbiol. Rev.

Cosentino D, Chenu C, Le Bissonnais Y (2006) Aggregate stability and microbial community dynamics under drying-wetting cycles in a silt loam soil. Soil Biol Biochem. https://doi.org/10.1016/j.soilbio.2005.12.022

Cui X, Song J (2007) Soil NH4+/NO3- nitrogen characteristics in primary forests and the adaptability of some coniferous species. Front. For. China

De Vleeschouwer F, Gérard L, Goormaghtigh C, et al (2007) Atmospheric lead and heavy metal pollution records from a Belgian peat bog spanning the last two millenia: Human impact on a regional to global scale. Sci Total Environ. https://doi.org/10.1016/j.scitotenv.2007.02.017 
https://doi.org/10.5194/bg-2021-265

Preprint. Discussion started: 3 November 2021

(c) Author(s) 2021. CC BY 4.0 License.

Denef K, Six J, Bossuyt H, et al (2001) Influence of dry-wet cycles on the interrelationship between aggregate, particulate organic matter, and microbial community dynamics. Soil Biol Biochem. https://doi.org/10.1016/S0038-0717(01)00076-1

Dobbie KE, Smith KA (2003) Nitrous oxide emission factors for agricultural soils in Great Britain: The impact of soil water-filled pore space and other controlling variables. Glob Chang Biol 9:204-218. https://doi.org/10.1046/j.1365-2486.2003.00563.x

Galloway Jn, Aber Jd, Erisman Jw, Et Al (2003) The Nitrogen Cascade. Bioscience 53:341. Https://Doi.Org/10.1641/0006-3568(2003)053[0341:Tnc]2.0.Co;2

Galloway JN, Townsend AR, Erisman JW, et al (2008) Transformation of the nitrogen cycle: Recent trends, questions, and potential solutions. Science (80-. ).

Gauch HG, Hwang JTG, Fick GW (2003) Model Evaluation by Comparison of Model-Based Predictions and Measured Values. In: Agronomy Journal

Giller KE, Witter E, McGrath SP (2009) Heavy metals and soil microbes. Soil Biol Biochem. https://doi.org/10.1016/j.soilbio.2009.04.026

Giltrap DL, Li C, Saggar S (2010) DNDC: A process-based model of greenhouse gas fluxes from agricultural soils. Agric Ecosyst Environ 136:292-300. https://doi.org/10.1016/j.agee.2009.06.014

Göransson H, Godbold DL, Jones DL, Rousk J (2013) Bacterial growth and respiration responses upon rewetting dry forest soils: Impact of drought-legacy. Soil Biol Biochem. https://doi.org/10.1016/j.soilbio.2012.08.031

Homyak PM, Allison SD, Huxman TE, et al (2017) Effects of Drought Manipulation on Soil Nitrogen Cycling: A Meta-Analysis. J Geophys Res Biogeosciences 122:3260-3272. https://doi.org/10.1002/2017JG004146

Hund-Rinke K, Simon M (2008) Bioavailability assessment of contaminants in soils via respiration and nitrification tests. Environ Pollut 153:468-475. https://doi.org/10.1016/j.envpol.2007.08.003

IPCC (2019) IPCC Special Report on Climage Change and Land: Chapter 4: Land Degradation. 1-112

Jones CM, Spor A, Brennan FP, et al (2014) Recently identified microbial guild mediates soil N2O sink capacity. Nat Clim Chang 4:801-805. https://doi.org/10.1038/nclimate2301

Kemper WD, Rosenau R, Nelson S (1985) Gas Displacement and Aggregate Stability of Soils. Soil Sci Soc Am J. https://doi.org/10.2136/sssaj1985.03615995004900010004x

Kesik M, Ambus P, Baritz R, et al (2005) Inventories of N2O and NO emissions from European forest soils. Biogeosciences. https://doi.org/10.5194/bg-2-353-2005

Khalil K, Mary B, Renault P (2004) Nitrous oxide production by nitrification and denitrification in soil aggregates as affected by $\mathrm{O} 2$ concentration. Soil Biol Biochem. 
https://doi.org/10.5194/bg-2021-265

Preprint. Discussion started: 3 November 2021

(c) Author(s) 2021. CC BY 4.0 License.

Khan S, Cao Q, Zheng YM, et al (2008) Health risks of heavy metals in contaminated soils and food crops irrigated with wastewater in Beijing, China. Environ Pollut. https://doi.org/10.1016/j.envpol.2007.06.056

Knutti R, Sedláček J (2012) Robustness and uncertainties in the new CMIP5 climate model projections. Nat Clim Chang 3:369-373. https://doi.org/10.1038/nclimate1716

Kremen A, Bear J, Shavit U, Shaviv A (2005) Model demonstrating the potential for coupled nitrification denitrification in soil aggregates. Environ Sci Technol 39:4180-4188. https://doi.org/10.1021/es048304z

Lado LR, Hengl T, Reuter HI (2008) Heavy metals in European soils: A geostatistical analysis of the FOREGS Geochemical database. Geoderma 148:189-199. https://doi.org/10.1016/j.geoderma.2008.09.020

Leffelaar PA (1988) Dynamics of partial anaerobiosis, denitrification, and water in a soil aggregate: Simulation. Soil Sci 146:427-444. https://doi.org/10.1097/00010694-198812000-00004

Li C, Aber J, Stange F, et al (2000) A process-oriented model of N2O and NO emissions from forest soils: 1. Model development. J Geophys Res Atmos 105:4369-4384. https://doi.org/10.1029/1999JD900949

Manzoni S, Schimel JP, Porporato A (2012) Responses of soil microbial communities to water stress: Results from a meta-analysis. Ecology 93:930-938. https://doi.org/10.1890/11-0026.1

580 Mertens J, Wakelin SA, Broos K, et al (2010) Extent of copper tolerance and consequences for functional stability of the ammonia-oxidizing community in long-term copper-contaminated Soils. Environ Toxicol Chem 29:27-37. https://doi.org/10.1002/etc.16

Miranda KM, Espey MG, Wink DA (2001) A rapid, simple spectrophotometric method for simultaneous detection of nitrate and nitrite. Nitric Oxide - Biol Chem 5:62-71. https://doi.org/10.1006/niox.2000.0319

Moyano FE, Manzoni S, Chenu C (2013) Responses of soil heterotrophic respiration to moisture availability: An exploration of processes and models. Soil Biol Biochem 59:72-85. https://doi.org/10.1016/j.soilbio.2013.01.002

Nicholson FA, Smith SR, Alloway BJ, et al (2003) An inventory of heavy metals inputs to agricultural soils in England and Wales. Sci Total Environ 311:205-219. https://doi.org/10.1016/S0048-9697(03)00139-6

590 Peacock AD, Mullen MD, Ringelberg DB, et al (2001) Soil microbial community responses to dairy manure or ammonium nitrate applications. Soil Biol Biochem. https://doi.org/10.1016/S0038-0717(01)00004-9

Petersen DG, Blazewicz SJ, Firestone M, et al (2012) Abundance of microbial genes associated with nitrogen cycling as indices of biogeochemical process rates across a vegetation gradient in Alaska. Environ Microbiol 14:993-1008. https://doi.org/10.1111/j.1462-2920.2011.02679.x

595 Rillig MC, Ryo M, Lehmann A, et al (2019) The role of multiple global change factors in driving soil functions and microbial biodiversity. Science (80- ) 366:886-890. https://doi.org/10.1126/science.aay2832 
https://doi.org/10.5194/bg-2021-265

Preprint. Discussion started: 3 November 2021

(c) Author(s) 2021. CC BY 4.0 License.

Ruyters S, Springael D, Smolders E (2013) Recovery of Soil Ammonia Oxidation After Long-Term Zinc Exposure Is Not Related to the Richness of the Bacterial Nitrifying Community. Microb Ecol 66:312-321. https://doi.org/10.1007/s00248-013-0210-7

600

605

610

615

620

625

Schlüter S, Henjes S, Zawallich J, et al (2018) Denitrification in soil aggregate analogues-effect of aggregate size and oxygen diffusion. Front Environ Sci. https://doi.org/10.3389/fenvs.2018.00017

Schurgers G, Dörsch P, Bakken L, et al (2006) Modelling soil anaerobiosis from water retention characteristics and soil respiration. Soil Biol Biochem 38:2637-2644. https://doi.org/10.1016/j.soilbio.2006.04.016

Sereni L, Guenet B, Lamy I (2021) Does Copper Contamination Affect Soil CO2 Emissions? A Literature Review. Front Environ Sci 9:29. https://doi.org/10.3389/fenvs.2021.585677

Signor D, Cerri CEP (2013) Nitrous oxide emissions in agricultural soils: a review. Pesqui Agropecuária Trop. https://doi.org/10.1590/s1983-40632013000300014

Steinnes E, Allen RO, Petersen HM, et al (1997) Evidence of large scale heavy-metal contamination of natural surface soils in Norway from long-range atmospheric transport. Sci Total Environ 205:255-266. https://doi.org/10.1016/S0048-9697(97)00209-X

Vásquez-Murrieta MS, Cruz-Mondragón C, Trujillo-Tapia N, et al (2006) Nitrous oxide production of heavy metal contaminated soil. Soil Biol Biochem. https://doi.org/10.1016/j.soilbio.2005.08.007

Vuichard N, Messina P, Luyssaert S, et al (2018) Accounting for Carbon and Nitrogen interactions in the Global Terrestrial Ecosystem Model ORCHIDEE (trunk version, rev 4999): multi-scale evaluation of gross primary production. Geosci Model Dev Discuss. https://doi.org/10.5194/gmd-2018-261

Wrage-Mönnig N, Horn MA, Well R, et al (2018) The role of nitrifier denitrification in the production of nitrous oxide revisited. Soil Biol Biochem 123:A3-A16. https://doi.org/10.1016/j.soilbio.2018.03.020

Wuana RA, Okieimen FE (2011) Heavy Metals in Contaminated Soils: A Review of Sources, Chemistry, Risks and Best Available Strategies for Remediation. ISRN Ecol 2011:1-20. https://doi.org/10.5402/2011/402647

XIONG Z-Q, XING G-X, ZHU Z-L (2007) Nitrous Oxide and Methane Emissions as Affected by Water, Soil and Nitrogen. Pedosphere 17:146-155. https://doi.org/10.1016/s1002-0160(07)60020-4

Zaehle S, Friend A (2010) Carbon and nitrogen cycle dynamics in the O-CN land surface model: 1. Model description, site-scale evaluation, and sensitivity to parameter estimates. Global Biogeochem Cycles 24: https://doi.org/10.1029/2009GB003521

Zandalinas SI, Fritschi FB, Mittler R (2021) Global Warming, Climate Change, and Environmental Pollution: Recipe for a Multifactorial Stress Combination Disaster. Trends Plant Sci xx:1-12. https://doi.org/10.1016/j.tplants.2021.02.011

Zechmeister-Boltenstern S, Schaufler G, Kitzler B (2007) NO, NO2, N2O, CO2 and CH4 fluxes from soils 
Table 1: $\mathrm{N}$ species measured in the soils at the end of pre-incubation period further used to initialise the DNDC model, mean modelled $\mathrm{N}-\mathrm{NO}_{3}$ stocks and mean emissions of $\mathrm{N}-\mathrm{NH}_{4}, \mathrm{~N}-\mathrm{N}_{2}, \mathrm{~N}-\mathrm{N}_{2} \mathrm{O}, \mathrm{N}-\mathrm{NOx}$ pre-incubation. A, B and C are replicates.

\begin{tabular}{|c|c|c|c|c|c|c|c|c|c|}
\hline \multirow[b]{2}{*}{ Ech } & \multicolumn{3}{|c|}{ Measured ( $\mu$ g.g soil ${ }^{-1}$ ) } & \multicolumn{6}{|c|}{ Modelled (gN.m $\mathrm{m}^{-2} \mathrm{~h}^{-1}$ for emissions, $\mathrm{gN} \cdot \mathrm{m}^{-2}$ for stocks) } \\
\hline & $\mathrm{N}-\mathrm{NH}_{4}$ & $\mathrm{~N}-\mathrm{NO}_{2}$ & $\mathrm{~N}-\mathrm{NO}_{3}$ & $\begin{array}{l}\mathrm{N}-\mathrm{NH}_{4} \\
\text { emissions }\end{array}$ & $\begin{array}{l}\mathrm{N}-\mathrm{N}_{2} \\
\text { emissions }\end{array}$ & $\begin{array}{l}\mathrm{N}-\mathrm{N}_{2} \mathrm{O} \\
\text { emissions }\end{array}$ & $\begin{array}{l}\text { N-NOx } \\
\text { emissions }\end{array}$ & $\begin{array}{l}\mathrm{N}-\mathrm{NO}_{3} \\
\text { stocks }\end{array}$ & $\begin{array}{l}\mathrm{N}-\mathrm{NO}_{3} / \mathrm{N}- \\
\mathrm{NH}_{4} \text { stocks }\end{array}$ \\
\hline 30_A & 4.3 & 0.1 & 15.3 & \multirow{3}{*}{ NA } & \multirow{3}{*}{ NA } & \multirow{3}{*}{ NA } & \multirow{3}{*}{ NA } & \multirow{3}{*}{ NA } & \multirow{3}{*}{ NA } \\
\hline 30_B & 4.0 & 0.2 & 14.4 & & & & & & \\
\hline 30_C & 4.5 & 0.2 & 14.3 & & & & & & \\
\hline 60_A & 6.9 & 0.1 & 18.8 & \multirow{3}{*}{ 2.28. $10^{-10}$} & \multirow{3}{*}{$2.2610^{-7}$} & \multirow{3}{*}{$1.310^{-4}$} & \multirow{3}{*}{ 1.3. $10^{-3}$} & \multirow{3}{*}{456.3} & \multirow{3}{*}{0.21} \\
\hline $60 \_B$ & 6.9 & 0.2 & 18.8 & & & & & & \\
\hline 60_C & 6.7 & 0.2 & 18.7 & & & & & & \\
\hline 90_A & 8.2 & 0.2 & 23.6 & \multirow{3}{*}{$2.64 .10^{-11}$} & \multirow{3}{*}{$6.2110^{-7}$} & \multirow{3}{*}{$2.710^{-5}$} & \multirow{3}{*}{$2.710^{-4}$} & \multirow{3}{*}{509.8} & \multirow{3}{*}{0.24} \\
\hline $90 \_\mathrm{B}$ & 12.6 & 0.9 & 24.0 & & & & & & \\
\hline 90_C & 8.8 & 0.2 & 24.2 & & & & & & \\
\hline DO_A & 5.4 & 0.2 & 26.1 & \multirow{3}{*}{$2.3510^{-10}$} & \multirow{3}{*}{$4.310^{-7}$} & \multirow{3}{*}{$1.110^{-4}$} & \multirow{3}{*}{$1.110^{-3}$} & \multirow{3}{*}{432.0} & \multirow{3}{*}{0.19} \\
\hline DO_B & 5.9 & 0.3 & 29.8 & & & & & & \\
\hline DO_C & 7.4 & 0.9 & 26.4 & & & & & & \\
\hline DR_A & 3.7 & 0.2 & 28.4 & \multirow{3}{*}{$2.36 .10^{-10}$} & \multirow{3}{*}{$3.7210^{-7}$} & \multirow{3}{*}{$9.410^{-5}$} & \multirow{3}{*}{$1.110^{-3}$} & \multirow{3}{*}{454.5} & \multirow{3}{*}{0.21} \\
\hline DR_B & 3.4 & 0.2 & 29.8 & & & & & & \\
\hline DR_C & 5.0 & 0.3 & 29.9 & & & & & & \\
\hline
\end{tabular}

Table 2: Percentage of variation in soil $\mathrm{N}-\mathrm{NO}_{3}$ stocks, soil N-NO ${ }_{3} / \mathrm{N}-\mathrm{NH}_{4}$ stocks, $\mathrm{N}-\mathrm{NH}_{4}, \mathrm{~N}-\mathrm{N}_{2}, \mathrm{~N}-\mathrm{NOx}$ and N-

a.

\begin{tabular}{|c|c|c|c|c|c|c|c|}
\hline $\begin{array}{l}\text { Moisture } \\
\text { condition }\end{array}$ & $\begin{array}{l}\text { Added Cu } \\
(\mathrm{mgCu} \mathrm{kg} \\
\left.\text { soil }^{-1}\right)\end{array}$ & $\begin{array}{l}\mathrm{N}-\mathrm{NO}_{3} \\
\text { soils } \\
\text { stocks }\end{array}$ & 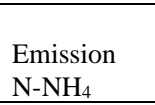 & Emission N-N ${ }_{2}$ & $\begin{array}{l}\text { Emission } \\
\text { N-NOx }\end{array}$ & $\begin{array}{l}\text { Emission } \\
\mathrm{N}-\mathrm{N}_{2} \mathrm{O}\end{array}$ & $\begin{array}{l}\text { Soil stocks N- } \\
\mathrm{NO}_{3} / \mathrm{N}-\mathrm{NH}_{4}\end{array}$ \\
\hline 60 & 0 & 0.0 & 0.0 & 0.0 & 0.0 & 0.0 & 0.0 \\
\hline 60 & 50 & -1.3 & 0.3 & -17.9 & -3.5 & -2.1 & -1.5 \\
\hline 60 & 100 & -2.6 & 0.6 & -24.4 & -5.5 & -4.1 & -3.2 \\
\hline 60 & 250 & -6.7 & 1.5 & -35.0 & -10.5 & -9.8 & -8.0 \\
\hline 60 & 500 & -13.3 & 2.9 & -45.6 & -17.8 & -19.0 & -15.7 \\
\hline
\end{tabular}


https://doi.org/10.5194/bg-2021-265

Preprint. Discussion started: 3 November 2021

(c) Author(s) 2021. CC BY 4.0 License.

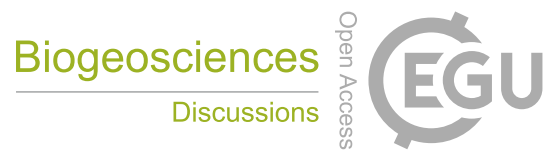

(c)

\begin{tabular}{|rrrrrrrr|}
60 & 750 & -19.5 & 4.3 & -53.4 & -24.5 & -27.7 & -22.8 \\
60 & 1000 & -25.4 & 5.5 & -59.8 & -30.6 & -35.8 & -29.3 \\
60 & 2000 & -44.5 & 9.7 & -78.0 & -50.5 & -62.3 & -49.4 \\
\hline 90 & 0 & 0.0 & 0.0 & 0.0 & 0.0 & 0.0 & 0.0 \\
90 & 50 & -1.0 & 0.3 & -16.4 & -6.7 & -3.1 & -1.2 \\
90 & 100 & -2.2 & 0.6 & -22.4 & -9.4 & -5.3 & -2.7 \\
90 & 250 & -6.0 & 1.5 & -32.3 & -14.5 & -11.1 & -7.3 \\
90 & 500 & -12.1 & 3.0 & -42.7 & -20.8 & -20.1 & -14.7 \\
90 & 750 & -18.0 & 4.5 & -50.7 & -26.1 & -28.4 & -21.5 \\
90 & 1000 & -23.6 & 5.8 & -57.4 & -30.8 & -36.2 & -27.8 \\
90 & 2000 & -41.8 & 10.3 & -76.4 & -46.0 & -61.6 & -47.2 \\
\hline
\end{tabular}

b.

\begin{tabular}{|rrrrrrrr|}
\hline $\begin{array}{r}\text { Moisture } \\
\text { condition }\end{array}$ & $\begin{array}{r}\mathrm{Added} \mathrm{Cu} \\
\left.\text { soil }{ }^{-1}\right)\end{array}$ & $\begin{array}{r}\mathrm{NO}_{3} \\
\text { soil } \\
\text { stocks }\end{array}$ & Emission $\mathrm{NH}_{4}$ & Emission $\mathrm{N}_{2}$ & Emission NOx & Emission $\mathrm{N}_{2} \mathrm{O}$ & ${\text { Stocks } \mathrm{NO}_{3} / \mathrm{NH}_{4}}$ \\
\hline DO & 0 & 0.0 & 0.0 & 0.0 & 0.0 & 0.0 & 0.0 \\
DO & 50 & -0.7 & 0.2 & -17.7 & -3.2 & -1.7 & -0.8 \\
DO & 100 & -1.5 & 0.3 & -23.9 & -4.8 & -3.2 & -1.8 \\
DO & 250 & -3.9 & 0.8 & -33.5 & -8.4 & -7.6 & -4.7 \\
DO & 500 & -8.1 & 1.7 & -42.8 & -13.6 & -14.8 & -9.6 \\
DO & 750 & -12.3 & 2.6 & -49.8 & -18.4 & -22.1 & -14.5 \\
DO & 1000 & -16.5 & 3.5 & -55.8 & -23.1 & -29.3 & -19.3 \\
DO & 2000 & -33.3 & 7.0 & -75.7 & -41.6 & -58.3 & -37.7 \\
\hline DR & 0 & 0.0 & 0.0 & 0.0 & 0.0 & 0.0 & 0.0 \\
DR & 50 & -0.6 & 0.1 & -17.6 & -3.6 & -1.6 & -0.7 \\
DR & 100 & -1.3 & 0.3 & -23.8 & -5.3 & -3.1 & -1.6 \\
DR & 250 & -3.5 & 0.7 & -33.3 & -9.1 & -7.3 & -4.2 \\
DR & 500 & -7.2 & 1.4 & -42.4 & -14.2 & -14.3 & -8.6 \\
DR & 750 & -10.9 & 2.2 & -49.1 & -19.0 & -21.2 & -12.8 \\
DR & 1000 & -14.5 & 2.9 & -54.8 & -23.5 & -27.9 & -16.9 \\
DR & 2000 & -28.6 & 5.7 & -73.2 & -40.7 & -54.1 & -32.5 \\
\hline
\end{tabular}




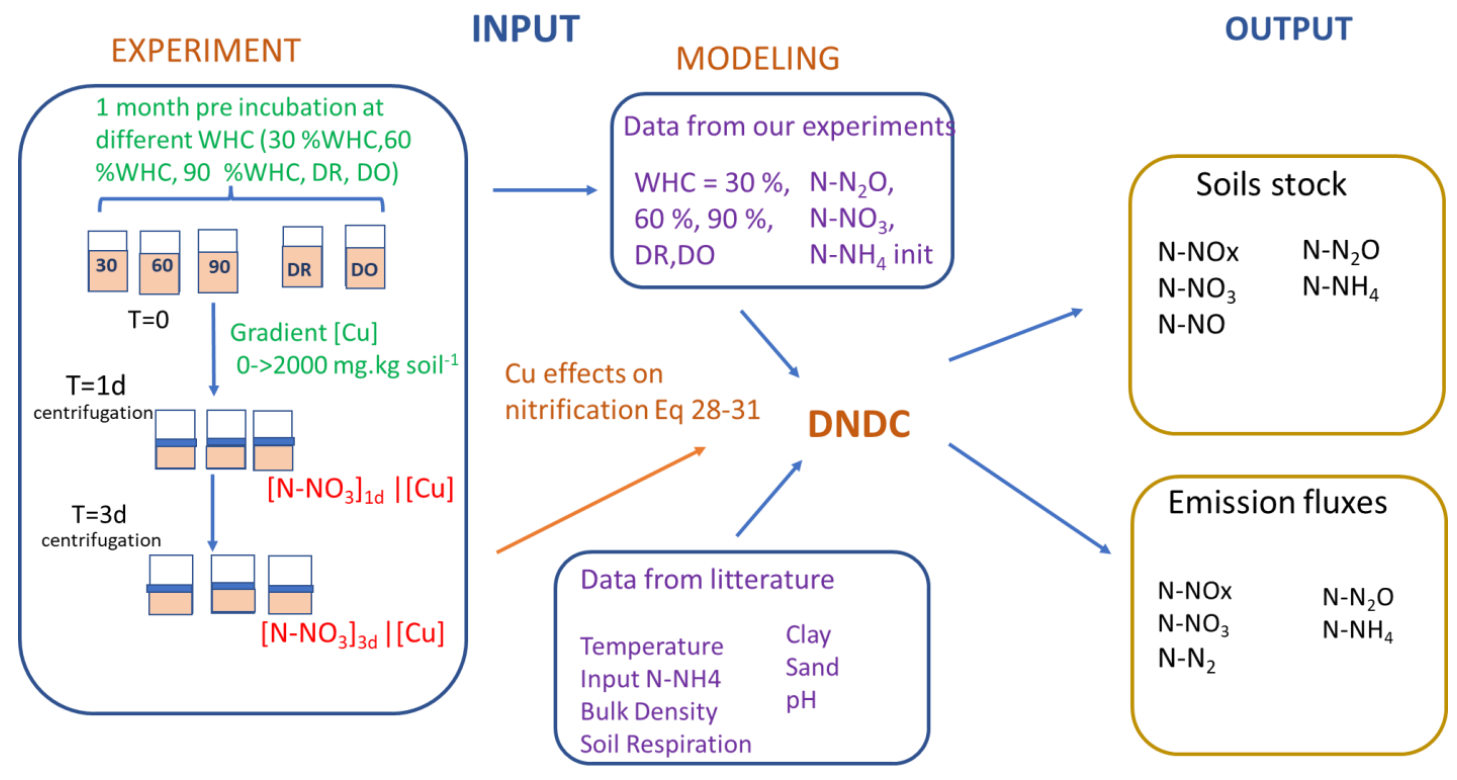

650 Fig. 1: Schematic representation of experimental and modelling procedures. Left refers to the experimental part and center to right to the modelling part. Soils were first pre-incubated 5 weeks at different WHC. N-NO, $\mathrm{N}_{2} \mathrm{NO}_{3}$ and $\mathrm{N}-\mathrm{NH}_{4}$ soil concentrations were then measured after this preincubation, and values were used to initialise DNDC. A bioassay was then applied on soil aliquots. Copper $(\mathrm{Cu})$ was spiked at 0, 50, 100, 250, 500, 750, 1000, $2000 \mathrm{mg} \mathrm{Cu} . \mathrm{kg} \mathrm{soil}^{-1}$ of soil to reach concentrations of 12, 62, 112, 262, 512, 762, 1012 and $2012 \mathrm{mg} \mathrm{Cu.kg} \mathrm{soil}{ }^{-}$

$655{ }^{1}$ and left for incubation. After 1 and 3 days of incubation, $\mathrm{N}-\mathrm{NO}_{3}$ production was measured in the supernatant. $\mathrm{N}-\mathrm{NO}_{3}$ productions against $[\mathrm{Cu}]$ gradients were used to define the functions of eq. 28 to 31 in $§ 3.1$. Soil respiration values were extracted from the curve $C_{i}$ of Fig 1 in Annabi et al. (2007). 
https://doi.org/10.5194/bg-2021-265

Preprint. Discussion started: 3 November 2021

(c) Author(s) 2021. CC BY 4.0 License.

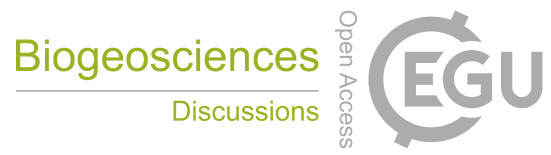

(c) (i)
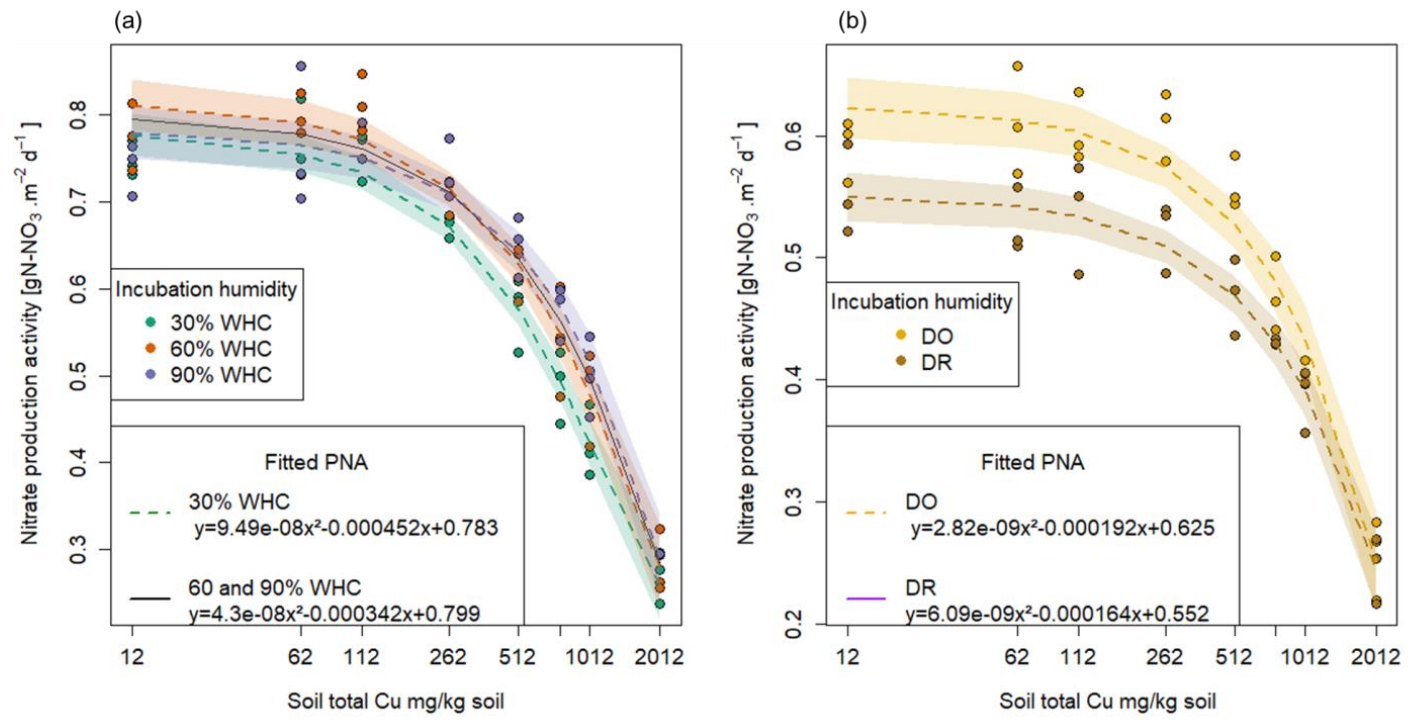

660 Fig. 2: Fitted functions of potential nitrifying activities against soil $[\mathrm{Cu}]$ for each moisture incubation condition. Points are the measured nitrate production and lines the fitted quadratic function with their $95 \%$ confidence interval.

(a). Constant moisture treatments: green is for $30 \% \mathrm{WHC}$, red for $60 \% \mathrm{WHC}$ and purple for $90 \% \mathrm{WHC}$. The black line is the common fitting function used for 60 and $90 \%$ WHC incubation conditions. (b). Variable moisture treatments: brown is for Dry-rewetting (DR) and yellow for dry only (DO). 
https://doi.org/10.5194/bg-2021-265

Preprint. Discussion started: 3 November 2021

(c) Author(s) 2021. CC BY 4.0 License.

(a)

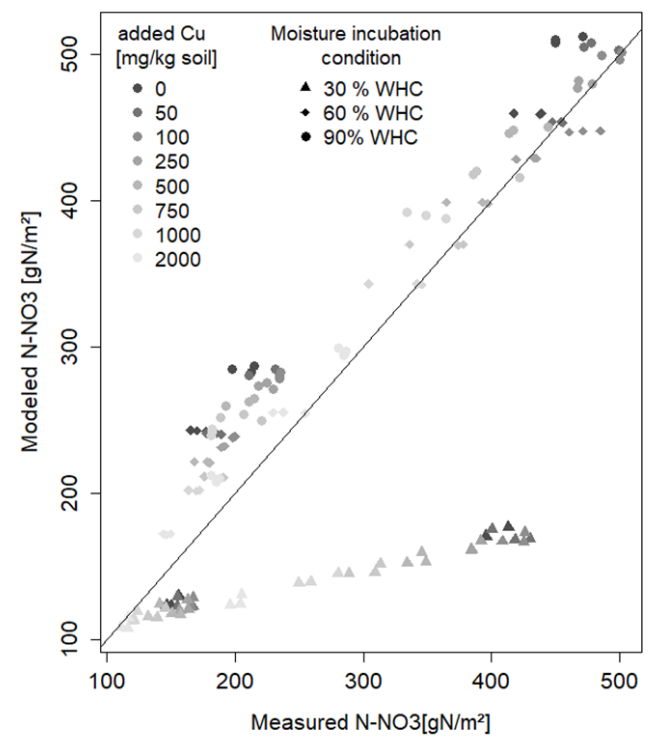

(b)

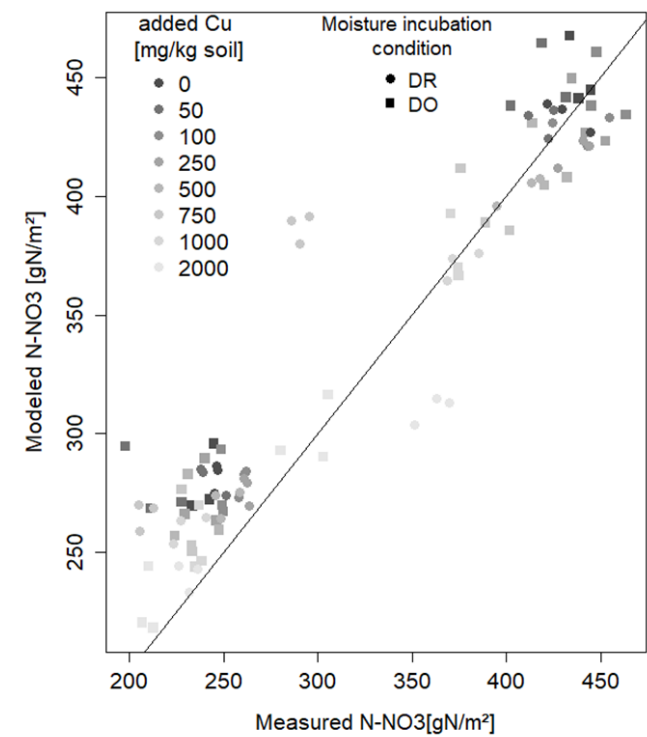

670

Fig 3: Comparison of modeled against measured soil [nitrate] incubated in different moisture. (a) $=3$ incubations under constant humidity. (b) = Dry-rewetting (DR) and Dry only (DO) conditions. For 30\% WHC, Model=1.84 * Measure and R2=0.93; for $60 \%$ WHC Model=0.93 *measure. R2=0.99; for $90 \%$ WHC Model $=0.90 *$ measure. $\mathrm{R} 2=0.99$; for Dry -rewetting $(\mathrm{DR})$ model $=0.96 *$ measure. $\mathrm{R} 2=0.98$; for Dry only 
https://doi.org/10.5194/bg-2021-265

Preprint. Discussion started: 3 November 2021

(c) Author(s) 2021. CC BY 4.0 License.

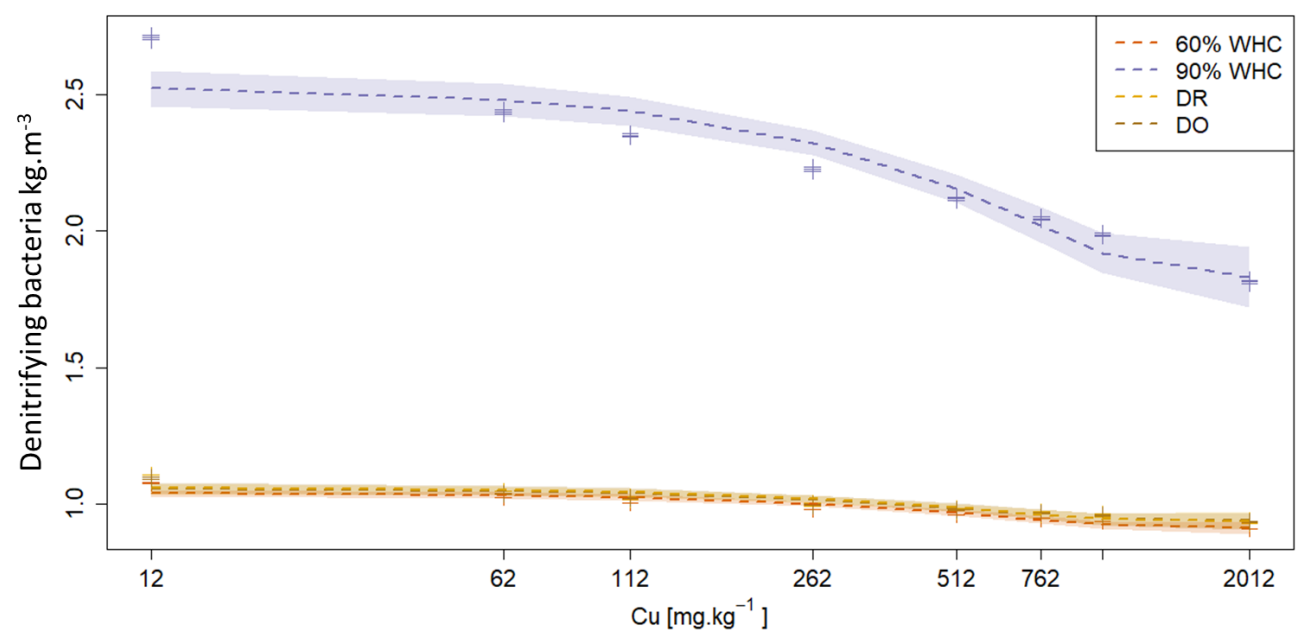

680 Fig 4. Modelled soil denitrifying bacterial pool after 3 days $\left(\mathrm{gN} \cdot \mathrm{m}^{-3}\right.$ soil) for the 4 moisture treatments. Purple is for $90 \%$ WHC, red for $60 \%$ WHC, brown for dry rewetting (DR) and yellow for dry only (DO). Red, brown and yellow curves being superposed. Pools were modelled for 12, 62, 112, 262, 512, 762, 1012 and $2012 \mathrm{mg} \mathrm{Cu}, \mathrm{kg}$ soil $^{-1}$ as represented by cross. Quadratic fits were used for representation. 

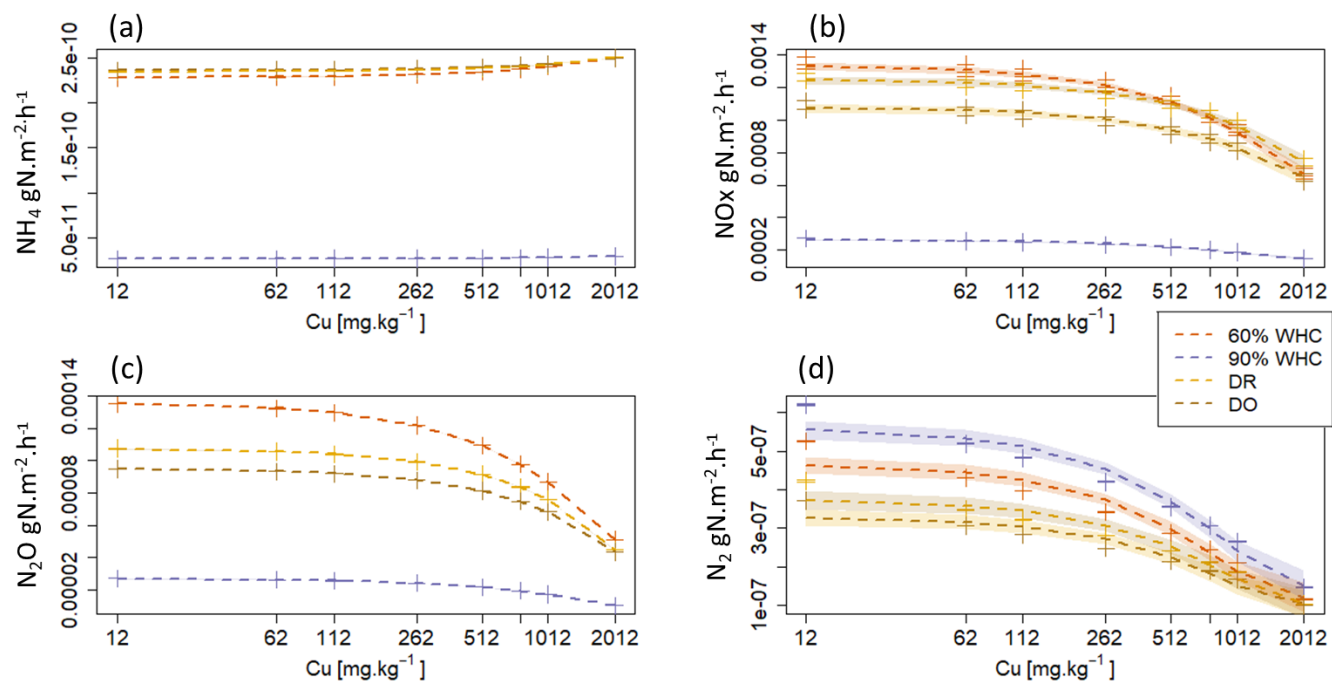

Fig 5: Modelled $\mathrm{N}$ emission fluxes at 3 days in $\mathrm{gN} . \mathrm{m}^{-2} .30$ min under the different moisture conditions. a.) $\mathrm{N}-\mathrm{NH}_{4}$ emission fluxes. b.) N-NOx emission flues c.) $\mathrm{N}-\mathrm{N}_{2} \mathrm{O}$ emission fluxes and d.) $\mathrm{N}-\mathrm{N}_{2}$ emission fluxes. Purple is for $90 \%$ WHC, red for $60 \%$ WHC, brown for dry rewetting (DR) and yellow for dry only (DO). Fluxes were modelled for 12, 62, 112, 262, 512, 762, 1012 and $2012 \mathrm{mg} \mathrm{Cu}$.kg soil $^{-1}$ as represented by cross. Quadratic fits were used for representation. 
https://doi.org/10.5194/bg-2021-265

Preprint. Discussion started: 3 November 2021

(C) Author(s) 2021. CC BY 4.0 License.

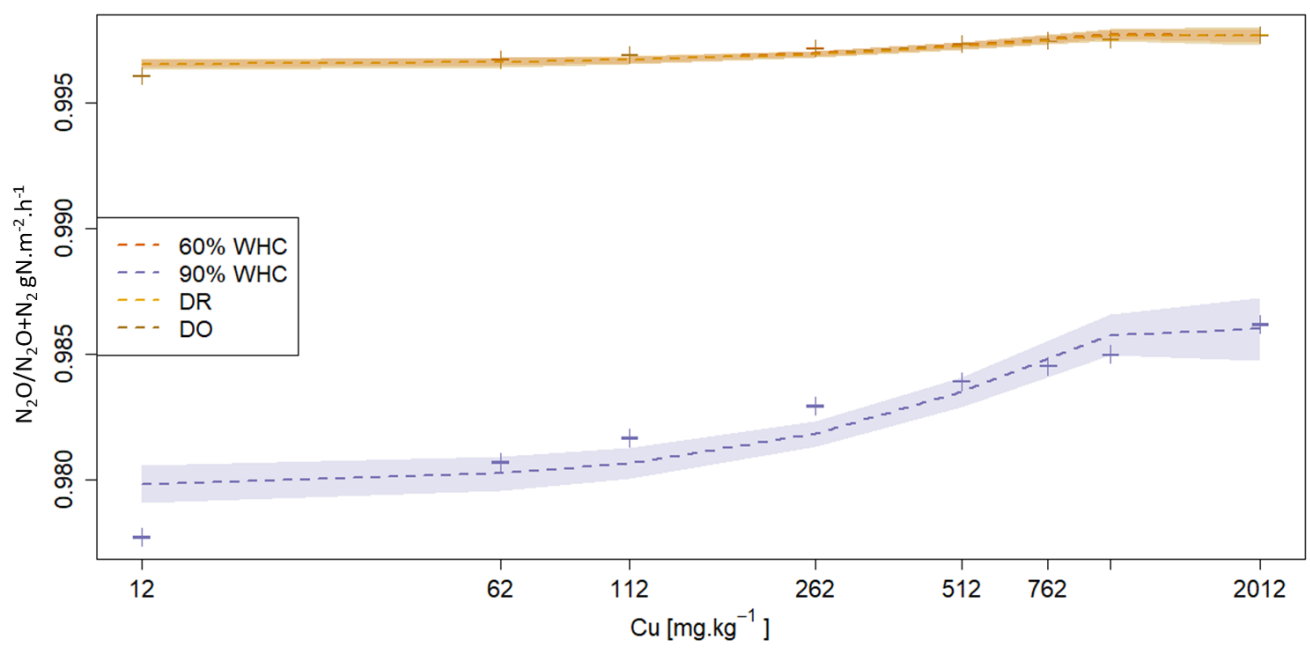

Fig. 6: Proportion of $\mathrm{N}_{2} \mathrm{O}$ emitted arising from the denitrification calculated as $\mathrm{N}_{2} \mathrm{O} / \mathrm{N}_{2} \mathrm{O}+\mathrm{N}_{2}$ modelled fluxes in response to soil $\mathrm{Cu}$ concentration for the various moisture conditions. Red is for $60 \% \mathrm{WHC}$, purple is for $90 \%$ WHC, yellow for the DR and brown for the DO. Red, yellow and brown curves are superposed. Fluxes were modelled for 12, 62, 112, 262, 512, 762, 1012 and $2012 \mathrm{mg} \mathrm{Cu} . \mathrm{kg}$ soil $^{-1}$ as represented by cross. Quadratic fits were used for representation. 